\title{
$-4 \sqrt{5}$ \\ 5982.9931 \\ 851
}

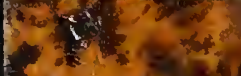

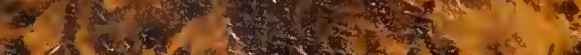

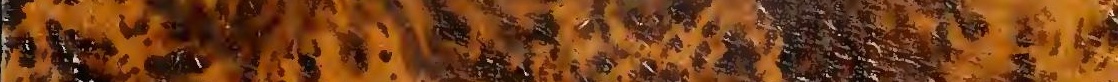

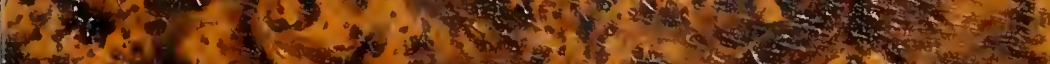

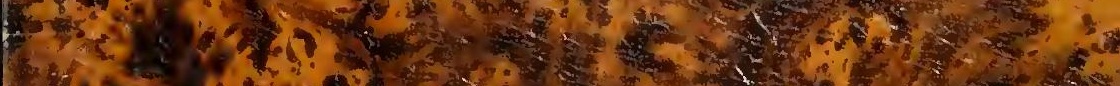
Q. 20 की

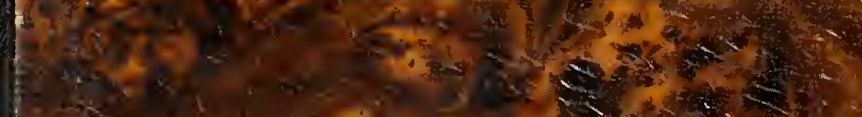

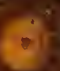

32

(f)

$0^{2}-5$

s

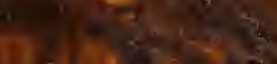

$x+4$

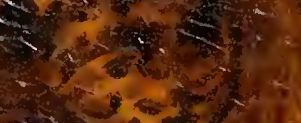

I.

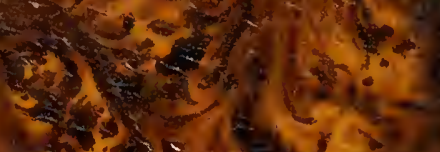

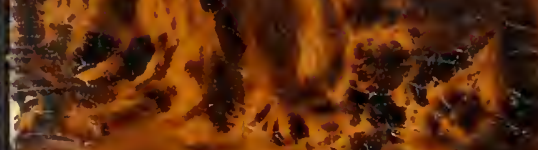

1.t. 3.

1.4 5.

3 s

$3 x^{4}=4$

$-\infty$

in 5

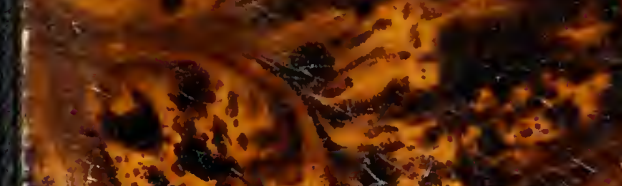

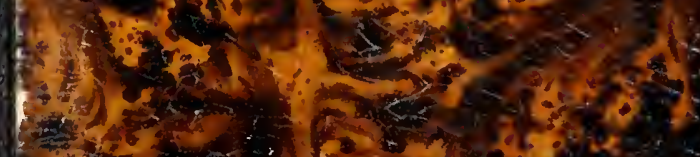

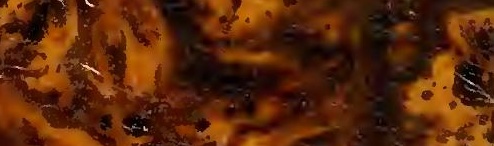

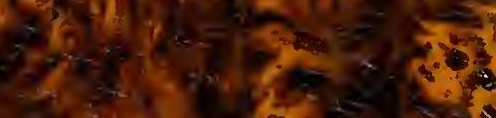

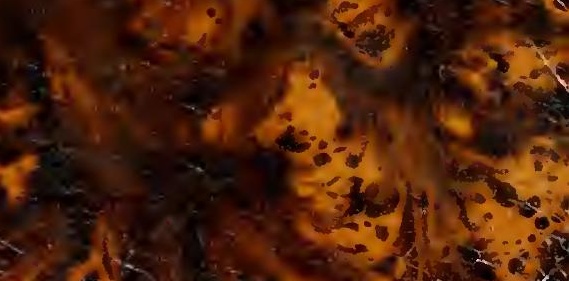

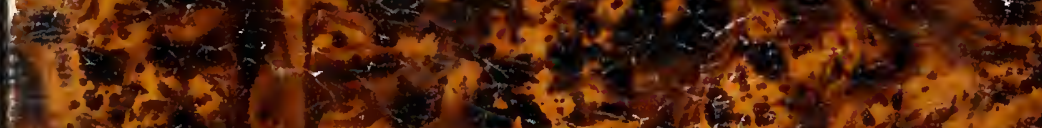

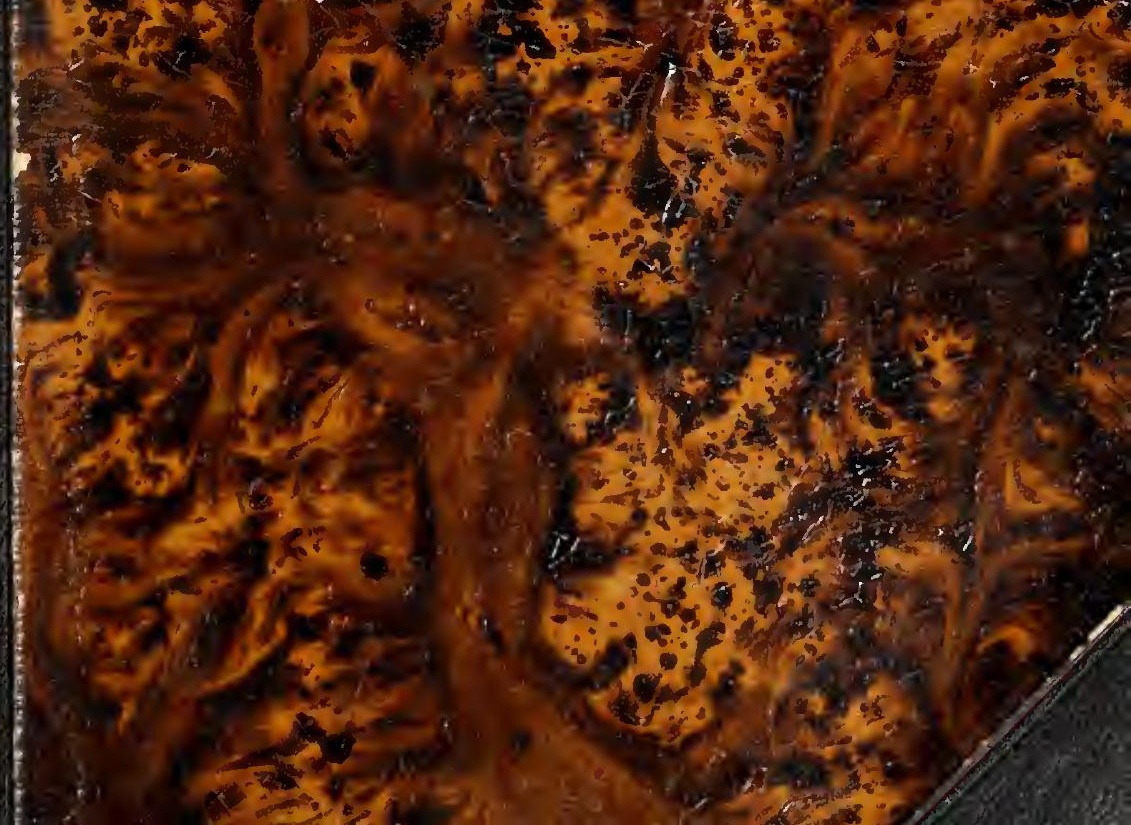




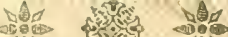

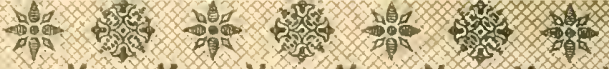

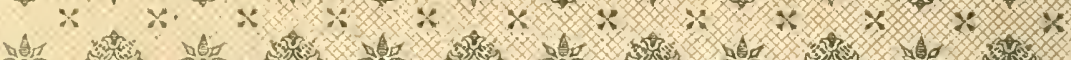

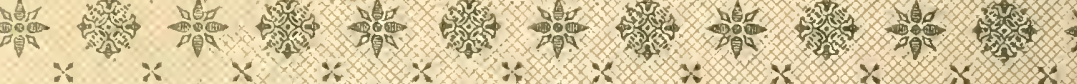

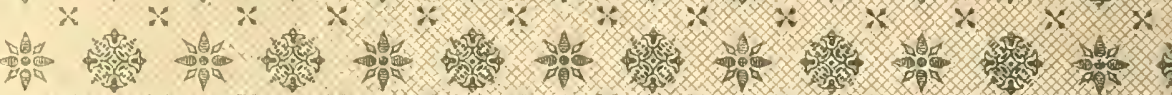

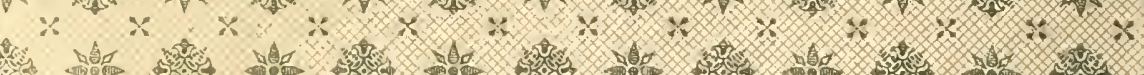

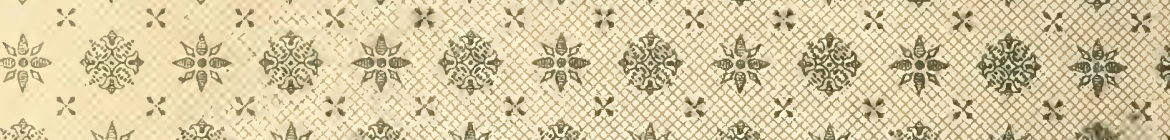

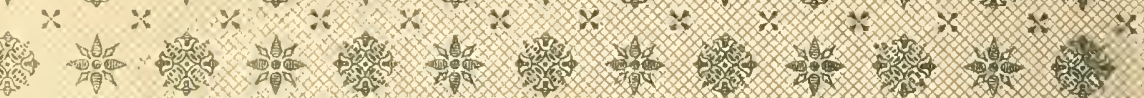

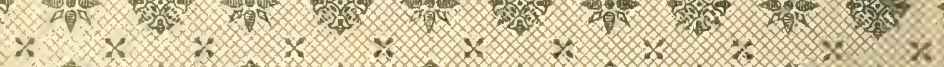

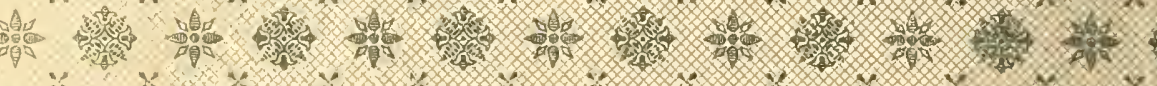

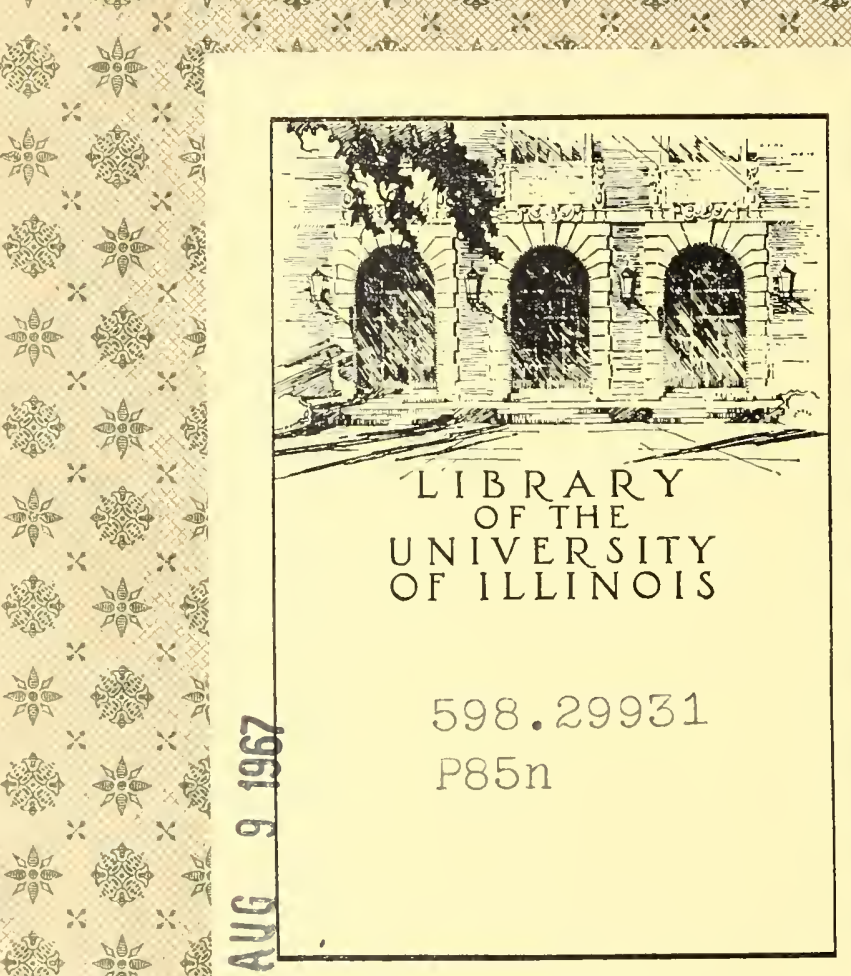

Biology

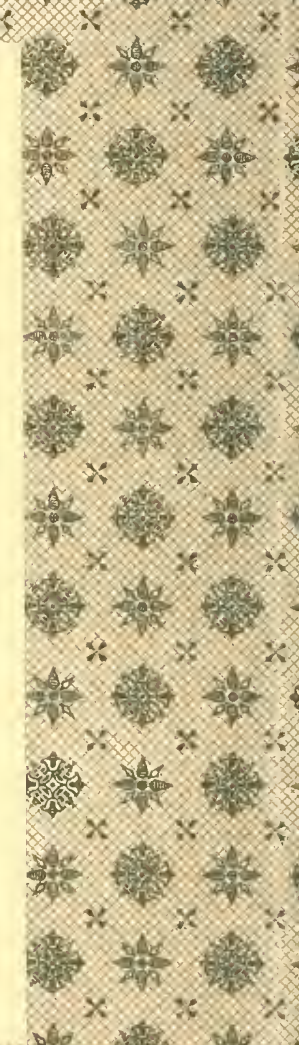

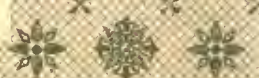
的

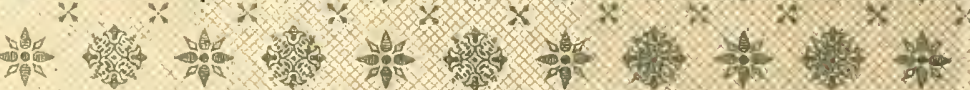
$\times x \times x \times x \times x \times x \times x$ 政 $\times \times x \times x \times x+x \times x$ 啳

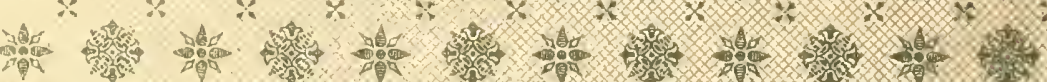

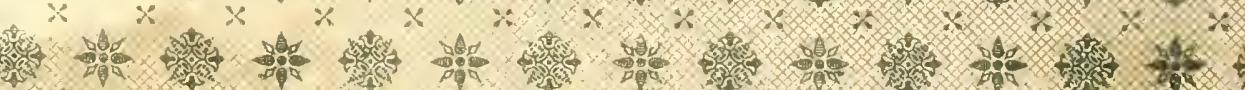







\section{Digitized by the Internet Archive}

in 2011 with funding from University of Illinois Urbana-Champaign 



\section{Iaul Levertiutm}

NOTES

OS THE

\section{BREEDING HABITS}

OF

NEW ZEALAND BIRDS.

BY T. H. POTTS.

READ BEFORE THE WELLINGTON PHILOSOPHICAL SOCIETY, JULY $17,1869$.

WELLINGTON : JAIES IUGHES, PRINTER, LAMBTON QUAY. 



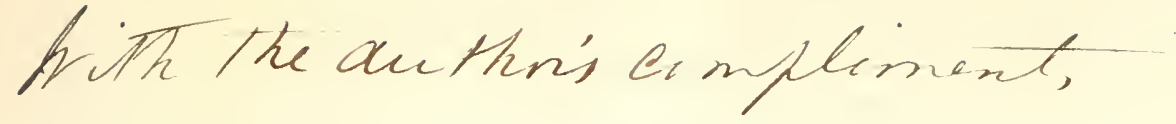

$\mathrm{NOTES}$

w TIIE

B REEIING HABITS

UF

\section{NEW ZEALAND BIRDS.}

\author{
BY T. H. POTTS.
}

(With Illustrations.)

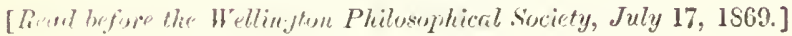

\section{INTRODUCTION.}

The settlers of New Zealand, so large a proportion of whom are engaged in rural occupations. which placing them in immediate contact with the works of nature, through ohservation and study ripening into confitential intercourse, will, donbtless, feel deeply inclebted to Mr. Buller for his valuable Essay on onr Binds, which most interesting division of onr Fauna exhibits a notable exception to the comprative dearth of animal life in these islands. When we consider, that from the absence of almost every variety of game, we are debarred the enjoynent of those sporting instincts and habits, which are characteristic of onr countrymen wherever they may sojouru, the Natural History of our birds may be found an interesting and useful study, wherewith tw begnile many a listless homr; wherever our pioneers of civilization are engaged in subhing the wilderness, near the grateful shade of the forest, in tending flocks on the hill pastmes, or cultivating the level acres of the plains.

Nor is it for the merits of that interesting treatise only that we feel thus indebted to its anthor ; its publication has called forth a critical review of it from the pen of Dr: Utto Finsch, of Bremen. The combined result has been of great advantage to the Studelit of Ornithology, by the removal of certain donbts and difficulties in the nomenclature, and the presentation of a nearly complete list of New Zealand birds, corrected to a recent date. Mr. Buller not only deserves well of his fellow-colonists for what he lias done, and merits our thanks for benefits conferre!l, but we must feel prospectively grateful 
inasmuch as he is labouring at a complete work on New Zealand Birds. As some time must, however, elapse before his work can be placed in the hands of the public, I beg to offer my small budget of information coneerning the mode of nidification and breeding labits of several species, which have come under my own observation, many of which are rapidly becoming scarce. I do so, not only in the hope of its proving of some utility, howerer slight, but also that others may be indueed to communicate their ouservations, even in a like imperfect shape, and thus lend their assistance in studying our page in the great Book of Nature.

Some of the information here given has been already forwarded to MIr. Buller, at his request, having been gathered from notes and memoranda, made by my sons, and myself, during a long residence in various districts of the Provinee of Canterbury, where we enjoyed favourable opportunities for pursuing a favomite study.

"Some to the holly hedge
Nestling repair, and to the thicket some;
Some to the rule protection of the thorn
Commit their feeble offspring : the eleft tree
Offers its kind concealment to a few,
Their fool its insects, and its moss their nests.
Others apart far in the grassy diale,
Or roughening waste, their humble texture weave.
But most in woodlands solitudes delight,
In mnfecuented glooms, or shaggy banks,
Steep, and divided by a babbling brook,
Whose murmurs soothe them all the livelong day,
When by kind dity fix'd." - THoxsos.

The Birds of New Zealand present to the observing naturalist most interesting studies in their breeding habits, and various modes of niditication, varying from the compactly-felted nest of the Rlipidure, or Mohoure, through easy gradations, every step of which is instructive, till we reach the bare spray-washed rock, on which the Whalebird rears its hardy offspring. They offer to our notice examples of burrowers, troglodytes or semi-burrowers, ground-builder's, parasites, and the more or less elaborately-finished structures, which are to be found amongst the incessorial families, in which division the faeulty or instinct of bird architecture appears to reach the highest development. Any one who has enjoyed the opportunity, must have been filled with admiration, whilst watching and considering the varying conditions under which the young of different species are reared.* We see that some are fed in the nest until they are well-grown, as the kingtisher and penguin; others may be said to assist the work of their parents, by following them as soon as they are hatched, and thus materially diminishing the labour of bringing up, by being themselves able to reach the locality of their food supply. Examples of these latter may be found amongst the Rallidie, Charadria, and Anatida ; whilst, as observed before, the young of the genera Halcyon and spheniscus (true burrowing species) remain in their tunnelled holes till well-fledged and wellgrown. Yet in the ease of Hymenolaimus melucorlynchus (which has some clain to be classed as a burrower), a young brood may be noticed with the old birds, on a lake or river, riding on the rippling wares, and floating with buoyancy and ease for hours. The Charadriae at the best are but indifferent

* In a recent work Professor Owen makes this suggestion, "A binary division of the class (Aves) may be founded on the condition of the newly-hatched young, which in some orilers are able to rum about, and provide food for themselves, the moment they quit the shell (aves preeoces); whilst in others the young are exclurler feeble, naked, blind, aurl dependent on their parents for support (aves altrices)." See Anatumy of Vertrbiata.-OWEx. 
nest builders, whilst some members of that restless, wary fumily make no attempt to provide artificial protection for their offspring, the young, warmly clothed with down, appear quite equal to the occasion, and accompany their parents with liveliness and aetivity. Amongst the Sternidie and Laridie, instances may be cited, showing equal indifference in proviling shelter for their young; yet, it should be remarked, in these cases the young appear quite incapable of shifting for themselres, and must depend on the inclustry of the old birds for bringing their foorl supply to them for several weeks. Here the parental instinct is shown in the selection of the breeding place, the eggs being deposited on the shore of the tishing ground, from whence the food snpply of the future family is to be procured; but they have fewer months to feed, as they seldom lay more than one or two eggs (L. Scopulinus, S. Longipennis). Now, if we turn, for the sake of comparison, to the incessorial genera, denizens of t! 8 bush, we shall find the callow nestling equally as helpless as the young in the case of the natatorial birds : but as they number many individuals to each nest, the tax on the energy of the old birds to supply the requisite amount of food, must cause, mo tanto, so much the greater labour, nnless, indeed, the warmth of numbers closely packed in a well-built nest, should rencler a somewhat less abundant supply of food sufficient, than would be required to support and rear the exposed broods of the aquatic birds before mentioned.

Some of the Grallatore and Anatida are remarkable for the extraordinary efforts they make when endeavouring to allure the unwelcome intruder from the immediate neighbourhood of their eggs or young. They will assume lameness, flutter with drooping wing, or drop with a dismal cry into the simulated agony of a cleath struggle to mislead the wayfarer, but when their artitice has succeeded in enticing him to follow till a safe distance from their precious charge is reached, "they clap their well-fledged wings and bear away," leaving the astonished beholder to melitate on the folly of trusting to appearances.

Amongst the troglodytal birds (such as Nestor, Platycercus, etc.) white is the usual colour of the eggs, donbtless as a provision to render their position more readily seen in the dim twilight of the breeding place, consequently to be approached and incubated with less danger of accident. It is, however, amongst the ground-breeders that the colouring of the eggs elicits the admiation of the careful observer; in some instances (such as Anarynchus frontalis) so wonderfully does the colouring of the eggs hirmonize with the prevailing tone of the ground on which they are deposited, that accident only would disclose their presence to the castal wanderer, besides the instance just given, $I I$. Longirostris, L. Scopulinus, afford noteworthy examples of this peculiar property which offers such a reliable safeguard against the phurtering propensities of bijerls, whether feathered or not.

The rapir dimimution in the numbers of our birds (with the exception of a very few varieties, of which Zosterops lateralis is the most noticealble instance) must be apparent to everyone who has giren the slightest consideration to the subject, it is a matter of deep regret that, in all probability, many species will have become extinct ere their liahits can be sufficiently studied by the naturalist for their use, economy, and position in our Fiuna to be correctly ascertained. To the future student of the natmal history of our country, vague, unreliable tratitions, a conflicting nomenclature, and the contorted productions of the taxidermist mounted in acrobatic and weird-like attitudes, will perhaps alone remain to fill up the liatus. How far shonld we now have to travel to discover a bery of Quail, in the seclusion of some very remote valley of the "back country," a straggler" or two might be met with. Yet by referring to the "New Zailand Irandbook," it may be noted that the liarge island in Port Cooper was named after this lired, from the number of Quail flushed theie. 'The beantiful little Rails are now almost as scarce; in low few 
streams or lakes could one now expect a sight of the nolle White Crame, watching "with motionless regard," its finny prey, yet but twelve years since, the writer of this paper gave Lake Heron, in the Ashburton comtry, its name, from the numbers of this majestic bird, which frequented its shores, or somed above its surface with lazy, heavy flight. These are but a few names of rure birds from a list that is ammally increasing ; and it is a matter of no great diffienlty to point to the canses, which have led to what must certainly be deemed a misfortune to the Colony.

As the country became occupied, the more remote districts rendered accessible by means of roads, as widle-spreading swamps were drained and brought into cultivation, extensive tracts of comntry stocked with cattle and sheep, above all, as the whole fice of the comntry became changed by the repeated bush fires, it can be readily understood how these various incidents of civilization should so soon have effected such considerable changes in the condition of our feathered tribes. To these other minor causes may be added, and, perhaps, contemplated with less satisfaction, the reckless gunner frequently killing for the mere love of slaughter, the self-complacent "new chum," with the inevitable firearms, even the learned savant will sometimes be tempted to destroy both old and young, especially of our rarer bircls, a fuvourable opportumity of procuring choice and desirable specimens being too great for resistance ; scientifie zeal thus overcomes good policy, and consideration for the future. Would not the re-establishment of some of our rarer species (many of which are excellent as articles of food) form a worthy, if not a noble, object of ambition for our Acclimatization Societies to achieve? * The difficulties attending such in undertaking woukd neessurily be great, there is no donbt, but diffieulties energetically encountered are sellom insuperable. To ensure anything like a successful issue being arrived at, certain conditions must be fulfilled, early action must be taken, an intelligent acquaintance with the habits of birds, would be indispensable, patience to endure considerable trouble, as well as occasional disappointment, and lastly, a small expenditure of noney. However, a molerate outlay should not be an impediment to an undertaking of such interest with those institutions, which have been handsomely supporter by private subscriptions, supplemented by liberal grants of public money. $\dagger$ The Parliament of New Zealand has taken steps to protect some of our birds, but however well legislative enactments may be framed, the people themselves can alone determine what shall be allowed to exist; looking at the rapid destruction threatening our noble forests, and in some eases our fisheries also, it must be admitted that the prospect of the preservation of our birds is the reverse of hopeful.

As a rule, we appear to live, work, and legislate for to-day, with not too much anxious thought for the to-morrow of those who are destined to succed us. Whatever may have been the result in other comtries which have been colonized by our race, whoever fairly writes the history of this comntry, will have to record how deeply the Anglo-Saxon settler has implanted his mark, by the alteration of the natural features it presented on his first arrival. Perhaps it wonld not be consiclered ont of place to offer a few general, but very brief,

* "One of the exciting canses of the rlestruction of every living native animal that can be met with is the pretence of enriching onr Museums, while at the same time the overstocked market in Europe render them, for the most part, unsaleable there; and it is a wellknown fact, that the skins of Australian birds, etc, have been re-exported from England to Australia for sale."-See Dr. Bennett's "Gatherings of a Naturalist in Australia."

+ Should our Acclimatizing Institutions require a precelent, they may refer to the "Bulletin de li Société Impériale Zoologicue d' Acclimatation, 1S64." Among the extraordinary prizes offered liy the Imperial Society, February, 1S6t, may be found,Reproluction in France of the Pinnatel (iroise (Tetreo Cupielo) la Gelinotte, meclal of $1,000)$ franes. 
remarks on the sturly of our ornithology, whicls presents a wile field for the instructive entertainment, even of those who do not enjoy the atvintage of much out-of-door oceupation, as diligent investigation will repay those who are disposed to devote time and attention to its careful consileration. The tegumentary system of birds is so remarkable and beantiful a feature, amongst the glories of Nature's landiwork, as at once to call for observation, the most heedless must be attrated by the exquisite arrangement of form and colon: Althongh man's chief interest in the feathered tribes centres, in the fict of their furnishing him with delicate and luxurions varieties of food, or anusement, and a mild excitement in the way of sport ; yet several species are so lovely in their gorgeous trappings, that biris of many kinds are kejt in at semi-clomestic state, merely foi the gratification their beanty imprarts to the beholder. Vast numbers, more fortunate perhaps, are eagerly pursued and slain, not for economical purposes of supplying foot or elothing, but that their ritted plumes may be wor'n as articles of personal adormment. Human vinity lias long since established this custom so miversally that neither age, sex or lace appeass exempt, and the chief of a Maori tribe donbtless feels as much pride in lis feathered head-dress plucked from the beantiful tratin of the snow-white Kotuku, as the bedizened wearer of ostrich plumes, whether a prinee or a peeress of one of the most civilized nations of Europe.

The Parroquet may be frequently olserved in confinement, and the Tui, liveliest of our Meliphagidre, quite as often perhaps barred within the limits of a dirty cage, has to exchange, for the dewy nectar of fiesh bush Howers, a monotonous diet of soaked bread or biscuit, and for this umpalatealble dole the unfortunate prisoner for life is expected to be lively and gary. The Maories of the South Island have long prepared the Mutton-bird, as a dainty article of food.

What can be more wonderful than the development from the incrt contents of an egg, of so sprightly a ereature as a bird; if we were not fumiliarized with this adminable and curions process of natme, it woul! be deened miraculous; it really appears typical of the Creation, and this must lave been felt, where the egg was looked upon as the symbol of the renoration of the living world, and the custom was introdnced, of suspending an egg in Eastern Chumches. A writer on the monasteries of the kast says, "as the egg contains the elements of life, it was thought to be an emblem of the ank, in which were preserverl the rudiments of the future world."

Passing over the embryological age, the period of incubation which represents the term of gestation amongst mammals, and the growtl of the young in all its stages of dependence, our attention is arrested by the anatomical structure of this class of vertebrates. The peculiar ariangement of the osseous and muscular systems, from whence the powers of locomotion in all their admirable variety are derived, should be carefully considered, flying, walking, hopping, climbing, swimning, or diving, from the constant exercise of which, birds depend for safety, or obtain their food strpply.

A transient glance at the structure of their skulls and heaks will satisfy the encuirer how happily thein forins are adapted for the halits and rarying conditions of the life of different sprecies. The strong hooker low of Nestor, hy the help of which it ripidly ascends the stems or branches of trees, is sufficiently powerful to rend down long strips of tough bark, such as that of Forgus solavelit; the soft bill of Hymenolaimus enables it to seenre small aquatie insects, eadflis womns, ete., in the monntain creek; the slemler curver mandibles of Recurvirostra are fitter for thrusting into the oozy slime of the swampy maxsh; with its strong loek, the ensmopolitan Hamatopus reulily breaks the shell-armour of the various hivalves that prove the tirle-washerl murt flats of our harbours ; the reason for the lateral curvature of the larate of the 
Anaryuchus, or Crook-billed Plover, as yet requires explanation, which can only be satisfactorily given from a closer olservation of its habits. Compare the bones of Himantopus, the graceful wader, with those of Porliceps, or Sphouiscus, chief amongst diver's, the wabbling, yet undulating gait of the latter, when hastening to the sea, gives it rather the appearance of a large water-rat than that of a lird, but how its awkwardness on shore is compensated for, anyone may jurlge who witnesses the ease and rapidity with which it dives beneath the swelling wave, by the aid of its fin-like wings. Notably, Fregata, Diomedia, Thalassilloma, with their enormous development of the bones and muscles of the wings, their consequent almost untiring flight, ${ }^{*}$ offer the most remarkable contrist to many species, such as Apteryx, Ocydronns, and the wingless giant peculiar to our land, which perliaps has not been long extinct. It is interesting to note that it was from a bone of this genus that the instance of the perfection of skill to which the accomplished anatomist can attain, was exhibited, as all the world knows, by Professor Owen building "up, from the study of a single bone, his theory of the gigantic bird, the correctness of which was afterwards corroborated ly the discovery of ample remains of various species of Dinornis. Is it possible that the Moa was known to the ancient world? The following passage from Strabo would answer for a description of its pursuit by natives, quite as well as for the hunting of the Dodo of the Mauritius, or the Epyornis of Madagasear. Writing of the comtries washed by the Red Sea (Book xvi.), Strabo observes, "Above this nation is situated a small tribe, the Struthophagi (or lird-eaters), in whose country are birds the size of deer, which are unable to fly, but run with the swiftness of the ostrich. Some hunt them with bows and arrows, other's covered with the skins of birds, they hide the right hand in the neck of the skin, and move it as the birds move their necks. With the left hand they scatter grain from a bag suspended to the side; they thus entice the lirds till they drive them into pits, where the hunter's dispatch them with cudgels. The skins are used both as clothes and as covering for beds." Such an ancient notice of a wingless bird is interesting.

The flight, migration, sight, and voice, of many of our species of birds, are all subjects of interest to those who are glad to learn sometling more of the world we live in.

When the Lark is flushed from her nest on the wide expanse of the tussockcovered plains, with what rare instinct or wonderful gift of sight must she be endowed, which enables her to find her nest amidst the myriads of tussocks presenting the same aspect, withont a track, a tree, or even a rock, as a guide to aid lrex organ of locality. How true is the Bronze-winged Cuckoo to his appointment, almost to a day, the first week in Octolver he announces, by his presence, that high spring has been reached, and the active labours of our portion of animated nature has commenced in earnest.

We camnot boast of possessing, amidst our bushes, rivals to those "melodious songsters of the grove" which wake up the woods and hedgerows of the Old Comntry, yet many of the notes and cries of our feathered race are peculiarly interesting, such as the song of the Petroica albifrons, the humanlike whistle of the Citrysococcyx lucidus, the well-known chime of the Bellbird, the extraordinary somds to which the white banded Tui gives utterance, the flute-like tones of the Crow or Wattle bird, the wailing call of the Weka; and the startling shriek of that night bird, frequently heard in the back country, which has not been identified as the call of any bird that has yet been described.

* After the memorable storms of July and August, 1867, in Lyall's Bay, amongst numbers of Hapuka and other fish that harl been stranded, we observerl several bodies of Diomedece exulans, that had perhajs becn dashed against the rocky cliffs, by the violence of the storm. 
For years attempts have been made to procure a specimen of this mysterious unknown, which will probably be found to belong to the families either of Strix or Podargus; it is to be hoper it may not turn ont to be the manliking bird thus mentioned by Fuller, "I have read of a bird which hath a face like, and yet will prey upon, a man, who coming to the water to drink, and finding there, by reflection, that he had killed one like himself, pineth away by degrees, and never afterward enjoyeth itself."

Alrearly some of onr mral settler's attach significance to the peculiar flight and cries of birds, as prognosticating changes in the weather, thus following ont in their new home the like fancies or observations which have been handed down by their fathers from time immemorial; on this subject Cuvier wrote, "For the rest of their intellectual qualities, their rapid passage through the different regions of the air, and the lively and continned action of this element upon them, enables them to anicipate the variations of the atmosphere, in a manner of which we have no idea, and from which, has been attributed to them from all antiquity, by superstition, the power of announcing future events."

Embryological research as fur as our birds are concerned is still a sealed book. This is a branch of science upon the importance of which Agassiz lays much stress; after speaking of the information he had acquired from the examination of bird embryos, he writes, "How very interesting it will be to continue this investigation amoug the tropical birds! - to see whether, for instance, the Toncan, with its gigantic bill, has, at a certain age, a bill like that of all other bircls; whether the Spoonbill Ibis has, at the same age, nothing characteristic in the shape of its bill. No living naturalist conld now tell you one word about all this." Investigations of this nature amongst the several genera peculiar to New Zealand, would be of value to science, and would offer an interesting field for new discoveries concerning ornithological facts, in our bright corner of the world, which the scientitic naturalist has not yet found time or opportunity to lay bare.

Accuracy of clescription is so necessary to establish facts, that it is fal preferable to give a few brief notes, the result of actual observation, rather than to supply pages of information gathered from hearsay; even in our humble researches, the untrustworthy character of report generally, has been experienced sufficiently often, to impart a certain amount of incredulity not easily shaken off; mythic treasmes have so frequently eluded pursuit, when the scene has been reached that should hitve disclosed specimens of more than ordinary interest, that no difficulty is felt in understanding how often fable creeps in, and becomes, in a measure, blended with truth in matters relating to Natural History.

On the other hand it is fur from safe to discard even the improbable, as imperfect description has before now converted the improbable into the apparently impossible, as a very early notice of the Hornbill will testify.*

* In 1330, Odoric tells of a bird as big as a goose, with two heads. In 1672, P. Vincenzo Maria describes a bird, also as big as a goose, but with two beaks, the two being perfectly distinct, one going up and the other down; with the upper one he crows or croaks, with the lower he feeds, etc. - Viaggio, p. 401.

In 1796, Paulre Paolino, who is usually more accurate, retrogrades; for he calls the bird "as big as an Ostrich." Accorling to him, this bird, living on high mountains where water is scarce, has the second beak as a reservoir for a supply of that element. He says the Portuguese call it Passaro di duos bicos. _ riay., p. 153.

Lastly, Lieut. Charles White describes the same birl in the Asiatic Researches. "It has a large doulble beak, or a large beak surmounted by a horn-like shaped manclible."Asiatic Res., iv., 401. The bird is a Hornbill, of which there are various species having casques or protuberances on the top of the bill, the office of which does not appear to be ascertainerl. How easy here to call Oiloric a liar! hut how unjust, when the mattcr has been explained. - Cathay and the way thither, Vol. i., p. 100. 
Many writers of Natural History appear to have made a practice of copying fiom their predecessors: the inconvenience of this arrangement is manifest, in that errors were thus allowed a very protracted existence, such as the falles which were for centuries supposed to clescribe the natural habits of the Kingfisher, etc. The writer of this paper was long hamed by the vignetie title of a popular work on British Birds, the engraving was supprosed to give a correct representation of Cinclus rquaticus, and nest; the lattcr as there figured, presented the conventional basin-shapred arrangement with eggs, all complete, the popular notion of a bird's nest in fact; now, in reality, the nest is a thick mossy dome-shaped structure, in which the pure-white eggs are concealed from view. Years after quite as great a shock was felt, when on inspecting a pulblic collection, he found that if he placed reliance on what he saw before him, Falcons must have laid Pigeon's eggs, Seagulls had produced those of the Turkey, whilst the Crested Grebe had achieved a Duck's egg. Careless mystifications such as these, should be avoided by those who are expected to impart information, as too improbable.

An attempt to show, more clearly, the extent which the ravages of a few years have inflicted on the numbers of our bircls, may perhaps be excused for the olject in view, we will therefore endeavour even at the risk of being tedious, to represent such a scene of the past as one might reasonably expect to meet with, almost daily, during a considerable portion of the year, at the place indicated. One of the most fitvourable localities for observing the habits, acquiring a knowledge of the notes and cries, and watching the flight of various biris, was not fir from the gorge of one of our great southern rivers, where the monotonous flatness of "the plains" gives way to a more broken and unduliting surface, as an extensive range of hills is approached. This range is on one side flanked by low downs enclosing a few shallow lagoons, here and there sparsely-wooded gullies intersect the lills, from whence flow two or three brawling creeks, that join and deepen into a swift and silent stream crossing the grassy that; the higher portion of this corner of "the plains" is stoney, whilst near the foot of the downs lies a swamp of no great extent.

Here upwards of thirty varieties of birds might be observed almost daily, and here too, or within a very moderate circuit, most of them breed.

Then our handsome Quail abounded, flying straight and low when flushed; the finding its slight humble nest filled with eggs, was no rare occurrence; or to see from amidst the snow-grass tussock, the Weka confidently emerge, or to hear the little Grass-bird ntter its molnanging note n-tick, u-tick, as rising on feehle wings that just sustained it to the sheltering grass, beneath the spreading leaves of a neighbonring flax bush, whence perhaps the Tit (Petroica) dirted to the ground from the tall flower-stalk, to snatch the larve of the grasshopper. Then the blue Pukeko, prince of Rails, often stalked through the rampo of the swaml, or the brown-streaked Bittern, with long ruffled neck, rose with deliberate flight; perchance lard by in the narrow outlet bounded by tufted stumps of carex, the light-eyed Teal slunk silently from view; or further' on, where the creek willened to a noiseless pool, the little Grebe with rosy breast, dived and sported with restless activity; close loy a group of sober Grey Ducks; whilst the watchful Paradise Drake basked on the sumny bank abore, his hearly eyes doubtless commanding a view of a certain snow-grass tussock, under the waving plumes of which, a cup-like nest of slown might lie securely hid. Then perhilps amongst the tall feather-tufted tohe-tohe reeds, and sawedged grass, a pair of Harriers haul huilt their rongh, flat-topped home, or floating high above on noiseless wing, alamed the pycbald Reallill, that cireles rouml on rapill wing, sereeching its clanomons note; or we might wateh the pied Stilt with long pink legs, ontstretched muler-like behind, making for the rush-firinged lagoon, to join its mates in waling near the margin of the pool, 
whose placid surface, now broken into a thousand ripples, as it shicers beneath the touch of the passing breeze, laden with sweet perfume, collected from the thorny Discaria, the formal solitary Cordyline, or the creamy bells of the brown-leaved Epacris. Now perhapss behind a favouring flax bush, we watch the visitors that dot the surface of the water (amongst them, the Black Widgeon and variegated Shoveller were rarely to be seen) and observe some early flappers skimming along in hot pursuit of their insect prey. Crossing towards the higher stony gromnd over patches of gizzard-stones, and many a bleached bone, crumbling in decay, of the giant Moa, that tells a tale of days philosophers may dream of; perhaps the sprightly lark, with lively chirmp, mounts from its freckled eggs, or the bunted Dotteril flies round with warning note, whilst its grey-clad young lide cunningly behind some stick or stone; or red-billed Terms gather round in screaming flrcks, returning from a blackened patch of new-burnt ground, that stretches far out on the plains, whilst from many a beak dangles the writhing lizard; or maybe the slowly repeated twit, twit, of the red-breaster? Plover chimes in, as it sidles slyly off with alternate run and lalt, nor conld you find its slight grassy nest till hialf a dozen times the ground had been stepped over. The rock-bound gully reached (the heights above, as New Year's day came round, ablaze with crimson Ratal lowers), from the swift stream below, amidst its noisy brawling with the rocks, arose the plaintive whistle of the Blue Duck, as with soft-fringed bill it explored each little foaming edidy ; or scrambling through the scrub, we might observe, on the rifted top of a lunge lifeless tree, the great Black shag, perched motionless; beneath, Bell-birds, with noisy blustering flutter, seck the konini, clinging to its brittle sprays, extract the honey of the pendint flowers; or ligh up, clear into the golden glow of sunshine, ascends the glistening Tui, discharging a whole volley of strange sounds; or perhaps from the rocky bush, the green-clad Parroquet descends, its harsh note repeated rapidly; where sand-flies gather thickest and in itate the rambler with their dusky swarms, the Fly-catchers, pied and black, flit around, then perching, spread their fan-like tails with twittering chatter, whilst from a bare branch above, the strong-billed Kingfisher keeps watch above the gurgling creek. Then we might note where the small striped Wren ciept round the lichen-covered trunk, or moss-clothed branches of some spreading shrub, or the grey warhler (Piripiri) with quivering notes fluttered near its cosy, dome-shaped nest; perhajs on a luge blackbirch the Kaka might be seen rending down the bark in long ribbon strips, to reach the insect dainties that lay housed beneath; or, with rapid flapping wing, the Pigeon seeking the straight-stemmed Kohi, whilst concealed by the rising tier's of leafy canopy, the bronze-winged Cuckoo whistled from the topmost bough. Emerging from the bush's dusky light, into the full glare of noon, we might perhapss have seen the Quail-hawk, rapidly ascending with spiral flight, till it appeared like a lark speck against the cloudless sky, its shrill jarring seream distinctly heard the while. Descending throngh groves of formal Ti palms, the steep, stone-paved terraces of the gi'ent river thit rushes in milky streams below, the large Grey Gull might perhaps be found feasting on the carcase of a sheep, stretched on a patch of dark-green tutu; or hard by the margin of the sandy spit, the little Gull was perched neat and trim as any quakeress, whilst the Black Stilt, with its measy cry of pink, pink, settled a few yards onwards, to lead us from its cronching young, or the Crook-hilled Plover seuttled slowly off with ontstretched wing. Those less common birls, the great White Crane, Avocet, and Sponbill Duck were seen at rarer intervals.

Now the scene is changed, and so thoroughly ; it seenis ahnost like a dream that such things were. The wookled gulleys denuded of timber, show amidst blackened stumps, some isolated shrubs, still green, of olcureal, liulat, or 
much-endming coprosma; the constantly recurring bush fires liave cleared off the stately Ti palms (so fragrant in early spring); dwarfed flax bushes, altered the condition of varions grasses, improving some for grazing, effected a speedier drainage, and dried up the shallow lagoons. Thousands of sheep now depasture on that well-remembered corner of "the plains," on those gently-swelling downs; instead of the varied cries of birds we have the bleating of flocks, the bark of the colley as it rounds up its charge, the loud crack of the stockwhip, the hearty curse of the bullock driver delivered "ore rotuudo ;" these changes form part of the evidence that testifies to the progress of our civilization.

If from some of the causes thus pointed out, or the raljid rate at which the timber forests have been wasted or destroyed, ${ }^{*}$ the introduction of bees (and the numbers of swarms met with in the bush may easily account for some diminution in the food of the Meliphagidx), the spread of cats, and even rats, or from the feeble hold on life which appears to be shared by every living thing that is indigenous, whether animal or vegetable, when bronght into contact with foreign influences, it shonld be deemed impossible to avert the impending fate which threatens the existence of many species of ou native birls, we must endeavour to find some compensation for so great a misfortune, in the success which has attended the introduction of foreign birds in many parts of the country. The Pheasint, Partridge, and Californian Quail, are amongst the best of the game birls that may be considered as established amongst us. The Black Swan, introdnced in Cinterbury to check the growth of another foreigner (wateress), Shell Parroqnet, Thrushes, Blackbirds, Larks, Chatfinches, Greenfinches, Sparrows, Starlings, etc., from increasing numbers, promise very soon to give additional interest to our rural scenery.

\section{JIST OF BLRDS}

DESCRIBED IN THIS PAPER, WITH THE MEASURENENTS OF THEIR EGGS.

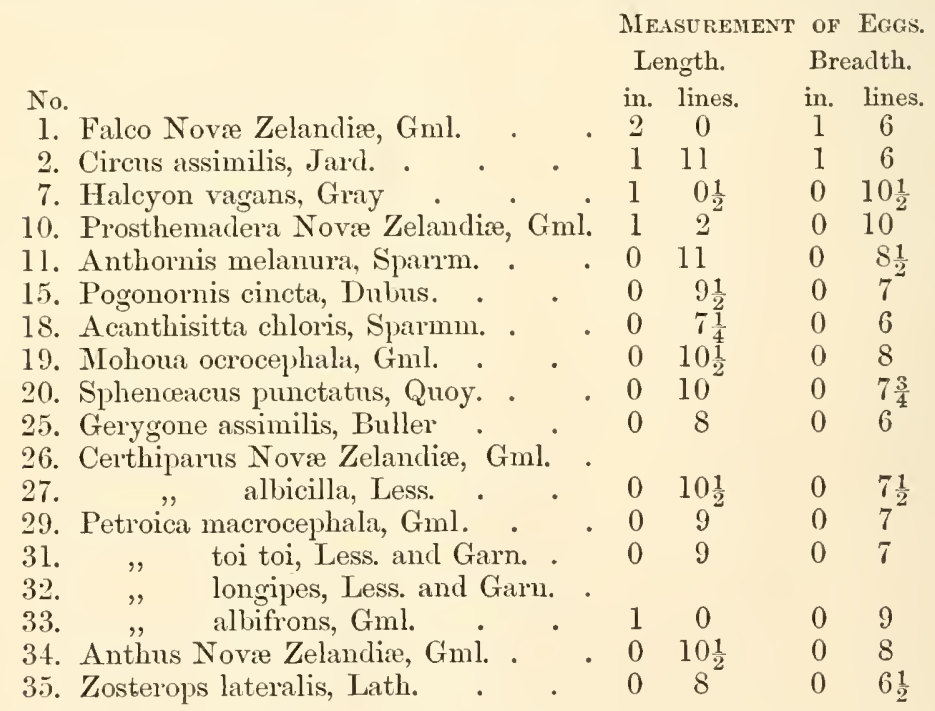

* According to a return recently laid before the Provincial Council, over upwarls of 170,000 acres of bush land, have depasturing licenses been granted by the Waste Lands Board of the Province of Canterbury. Is it the interest of the licensees to preserve timber? 
in. lines. in. lines.

38. " fuliginosa, Sparm. - $\begin{array}{lllll}0 & 8 & 0 & 6\end{array}$

47. Platycercus Novie Zelandiz, Sinrm. $1 \quad 1 \frac{1}{2} \quad 0010$

50. $\quad, \quad$ auriceps, Kuhl. . . $\quad 0 \quad 11 \frac{1}{2} \quad 0 \quad 9 \frac{1}{2}$

51. Nestor meridionalis, Gml. . . I $99^{2}$ l $3 \frac{1}{2}$

58. Chrysococcyx hucidus, Gml. . $\quad \begin{array}{cccccc}0 & 9 & 0 & 6^{2}\end{array}$

60. Cotunix Nove Zelandire, Quoy. . $1 \quad 3 \quad 0011$

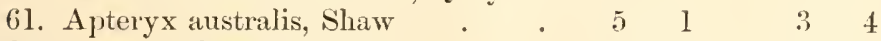

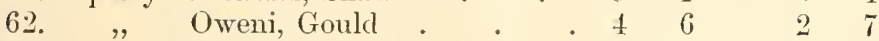

63. ", Mantelli, Bartl. . . $\quad 5 \quad 4 \quad 5 \quad 3 \quad 3$

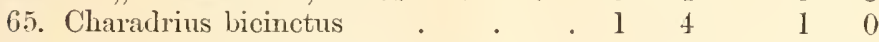

A. 65. $\quad, \quad$ obscurus, Gml. $\quad$. $\quad$. $\quad \begin{array}{llllll}1 & 9 & 1 & 3\end{array}$

B. 65. Anarhynchus frontalis, Quoy. . . $1 \quad 4 \frac{1}{2} \quad 1 \quad 0 \frac{1}{2}$

71. Hrematopus longirostris, Vieil. $\quad 2 \quad 2 \quad 3^{2} \quad 1 \quad 7 \frac{1}{2}$

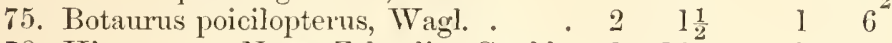

78. Himantopus Novie Zelandire, Gould $140^{2} \quad 1 \quad 3$

B. 78. " melas, Homb. . . $110 \quad 1013$

87. Ocydromus australis, Sparmm. $\quad \begin{array}{lllll}2 & 2 \frac{1}{2} & 1 & 5 \frac{1}{2}\end{array}$

91. Porphyrio melanotus, Temm. • . $20^{2} \quad 1 \quad 5 \frac{2}{2}$

92. Casarca variegata, Gml. $\quad$. 27 I 10

93. Anas superciliosa, Gml. . . . $\quad \begin{array}{lllll}2 & 3 & & 1 & 9\end{array}$

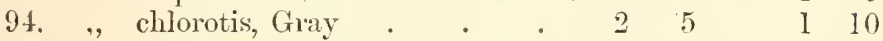

96. Fuligula Nove Zelandie, Gml. $\quad 2 \quad \begin{array}{lllll} & 8 & & 1 & 9\end{array}$

98. Hymenolaimus melacorhynchus, Gml. $20 \begin{array}{llll}81 & & 1 & 9\end{array}$

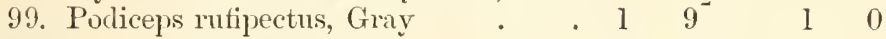

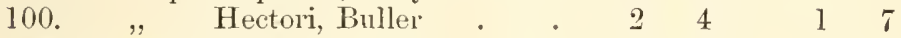

104. Spheniscus minor, Forst. . $\quad$. $\quad$. $2 \begin{array}{llll}2 & 3 & 1 & 9\end{array}$

126. Larus Dominicums, Licht. . . $\quad 2 \quad \begin{array}{llll} & 2 & 10 & 10\end{array}$

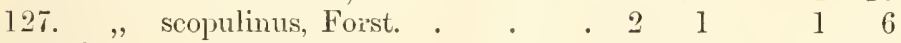

129. Sterna caspia, Pall. $\quad$ • $\quad$. $\quad \begin{array}{lllll}2 & 7 & 1 & 9\end{array}$

130. " longipennis, Nordm. . . 1 10 144

131. " antaletic $\%$, Forst. . . $\quad 1 \quad 6 \quad 6 \quad 1 \frac{1}{2}$

A. 131. " sp. (Stentula nereis), Qy. • 1 $44 \quad 0 \quad 11$

139. Graculus brevirostris, Gould $\quad 2 \quad \begin{array}{llll}2 & 6 & 1 & 6 \frac{1}{2}\end{array}$

142. Dysporus serrator, Banks. . . $3 \quad 1 \frac{1}{2} \quad 1 \quad 10$

It may be interesting to persons acquainted with the Oology of Europe, to institute a brief comparison between the eggs of some of our birds, and those of kindred European species; in some few, considerable contrast in size and shape, may be observed; whilst amongst others so little difference is to be discerned, that it would be rliftienlt to decide, from transient inspection, of which hemisphere they are native.

The eggs of Fulco Love. Zelandice closely resemble those of $F$. peregrinus, in size, form, and colour; so also do those of 'ircus assimilis bear as striking a likeness to those of $C$. mutus. The eggs of Halcyon vagans are larger than those of Alcedo ispida, the same nay be said of those of Coturnix Nove Zelandice, when compared with those of C. vulgris. To select the eggs of Hcemutopus longirostris, from a number of those of $I I$. Ostralegus, would be difricult; nor would it be much less so to decide whether the Bittern's eggs were European or New Zealand; the eggs of $/$ imerntopus melamoterus strongly resemble those of our Stilts, the same remark will apply to those of Podiceps minor and rufipectus, respectively. With regard to the egoss of $P$. cristutus, they are smaller than those of $P$. IIectori. The eggs of Sterme caspia bear a rery close resemblance in both hemispheres. The similarity between the egrss of sterna 


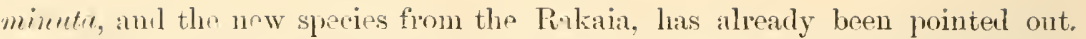
The egg of Dysiporpus serritur wnly differs by $1 \frac{1}{2}$ lines in length, from that of Siele vllue of Europe; whilst similar chalky encrustations may be found on either specimen.

\section{No. 1.-Falco Nove Zelande, Gml. \\ Ka rewal rewa-tara. \\ Quilil-hawk.}

In New Zealand, the courageous fimily of the Raptores is very feebly representerl, the honomalle post, of head of the family must fairly be assigned to this hird, which is commonly known by the name of the Quail or Sparrowhawk; "the harly sperhanke eke the Quales foe," as Chancer has it. This bold little Falcon, which, a few years since, was so frequently seen, is now of compratively rare occurrence. How seldom do we now hear that wild chattering scream, which gave notice of its approach, and spread alarm amongst the denizens of the poultry yard. Many instances might be cited of its daring courage and perseverance in pursuit of its prey, sich as dashing into houses, penetrating to an inner room, striking its quarry, and clinging to it till ruthlessly knocked over with a stick. Years ago, when Quail shooting, how we have been troubled by the assiduous attendance of this bird, and have shot this dauntless fowler almost in the act of swooping off our game. We have noticed the female, with a Tui trussed in her talons, which she carried a considerahle distance without a rest, when the male soared boldly in company, and kept watch and ward over his well-laden helpmate.

At present it is in the "back conntry" only, that we can hope to find its breeding-place, which is usually on a ledge of rock commanding a prospect over some extent of country. Such an out-look gives an advantage of no little value, of which the Falcon is not slow to avail itself, should such a bird as a Tui or Pigeon appear in sight.

Several of the breeding-places, which we have had opportunities of examining, have presented, in a remarkable degree, very similar conditions as regards sitnation." Amongst bold rocks on the mountain side, somewhat sheltered by a projecting or overhanging mass, appears to be the fivourite site for learing its young. The eggs very closely resemble those of $F$ ulco peregrims of Emrope, in colomr, size, ind sliape, ustully three in number, are deposited on any decayed vegetable matter, that wind or rain may have collected on the rocky ledge, for the efforts of this bird in the way of nest building are of the feeblest deseription. The eggs are of a rich redilish-brown, mottled over with darker shades of lrown, sometimes the ground-colour is pale reddish-white, less suffused with the dirker colour at the smaller end, broadly oval in shape, they measure 2 inches in length, with a diameter of 1 inch 6 lines. Some eggs taken from a range near the head-waters of the Rakaia, give measurements somewhat less than the above, with a yellowish, in place of reddish-brown colour. Young birds are covered with grey down at first, and assume a plumage of dark brown above, with breast of rufous-white spotted with brown, thighs slightly rufous. October, Nover.ber, arid December is the principal breeding season, and the localities we have noted for the eyries, are rocks near Cass's Peak, Goveruor's Bay, Malvern Hills, River Potts, Mount Harper, ete.

Notes.-Oct. 10 -Young Quail-hawks, near the home paddocks on the Rangitata River.

Nov. 8-Above the upper gorge of the Ashburton or Haketere River, foumd a nesting-place on the bare soil, sheltered by a large isolated rock; two young birds, covered with grey down, old birds very bold in defence of their young. 
2 liniterasinelis Haemalop. Waginashi-

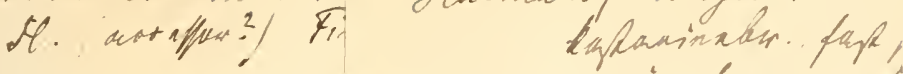

(apporocimans) (Gouldii)

4. Uthene albifacies

y Hadryan nagans

H. Antaormir melame

12

melanacep

lemainin yaft

ation Madiar. caleosniras

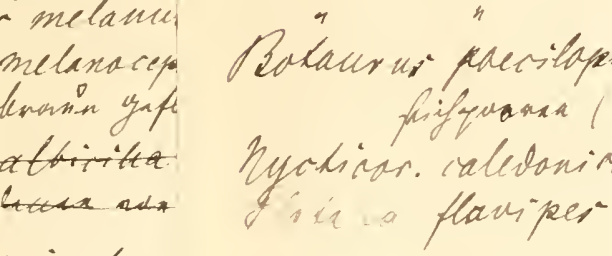

2h. Gerygore igata:

" I flaviventris

* (avinilis)

24. "albofrantata 34. Antmus ur.-zeel. Rerumuirarkna nudriralis year,

37. Thipisine flabe.

45: breadion camusuch

5s. Atringeper habrape

$5 \%$. Udynamis daiten.

58. laryoroce, lutilit nay fiofly la Minilif.

59 longe apdla ga naw

Himantop. nov. zed.

1. grass Limara unapygialis stwen iningth, aher fymorpouars m. ifrom miniza yman Pas. (eding

Raller asormilis Gr. (pector arr to Frmabala A. a. fo.fury ;

ondygametra tahuenvis 3 falcempennis af some

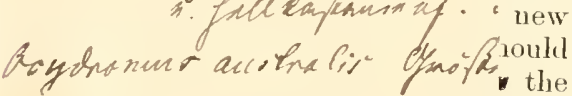
54 on of parpale spertso on

bI Aplenyx aurtralis 63 " (marklli) fults, genth),

62 Saryahyrio mela natus-m: soeary, Mrafl. gnim atm- veless $53.2+$ that

Anas rapenciliora sg. 5 tills s.9 theen

65. Chanatr. Lirvix

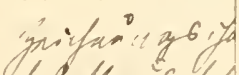

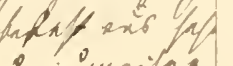
$\therefore \sin ^{2} \ln x$ 66 a falona To Thinarnire (Aacmat." thenizs cysatis

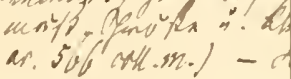

the ften 


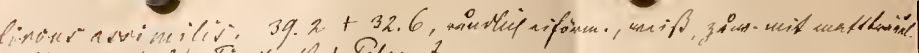

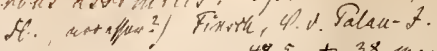

$48.5+38$ maip (youls, P.C.)

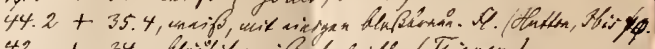

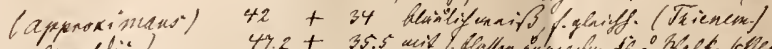

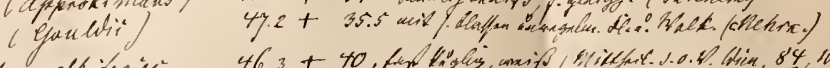

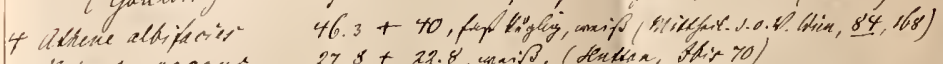

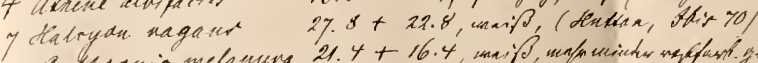

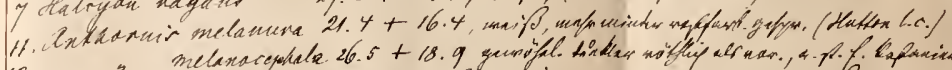

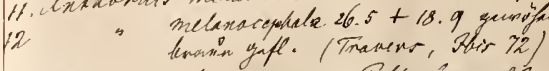

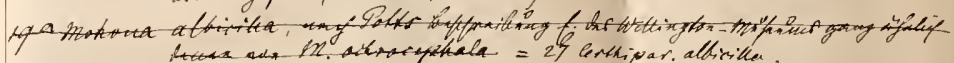

2h. Gerygore igaka

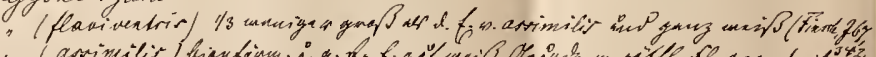

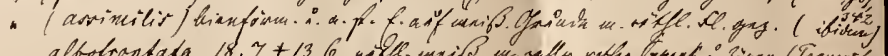

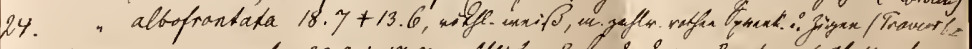

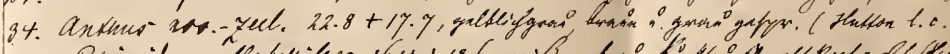

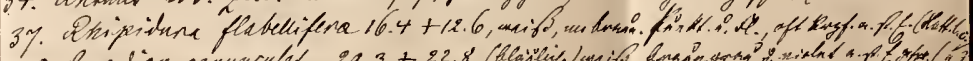

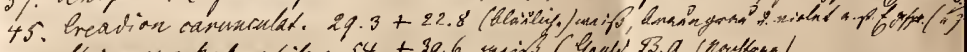

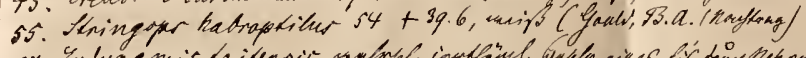

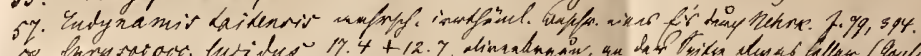

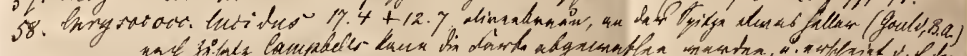

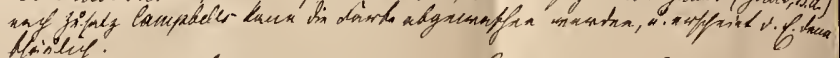

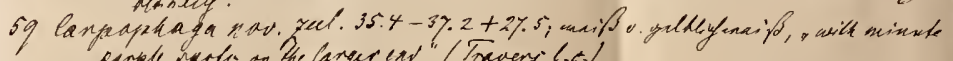
panple sperte on the largerest" ( Trevers. l.e.)

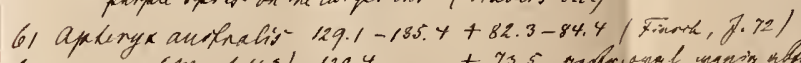

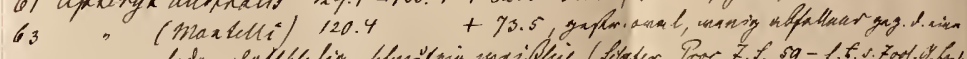

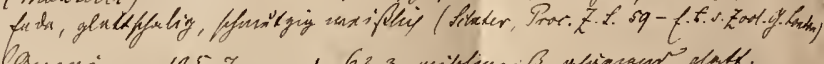

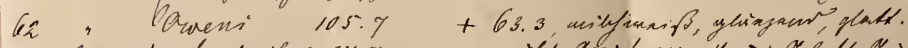
65: Charastr. hirvix

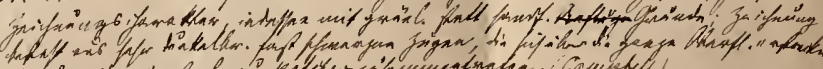

66

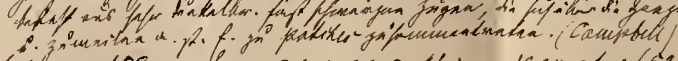

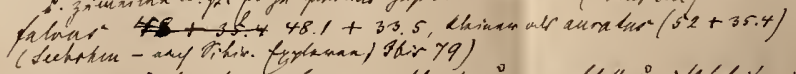

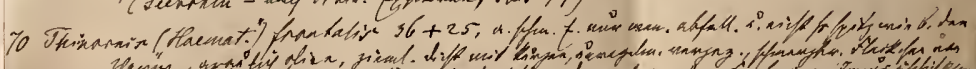

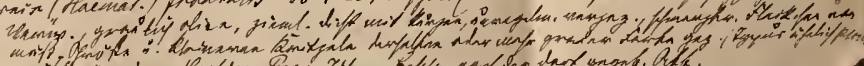

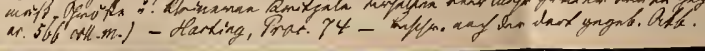




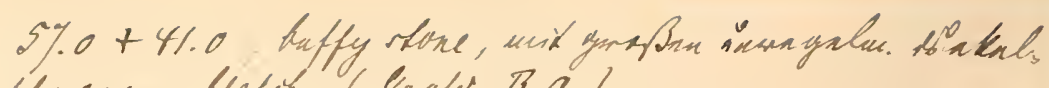
ifmangar blotit. (Goalo, B.a.)

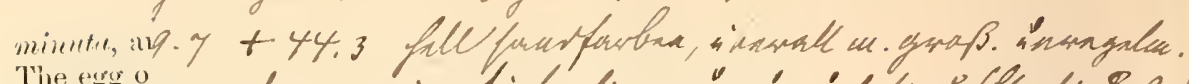

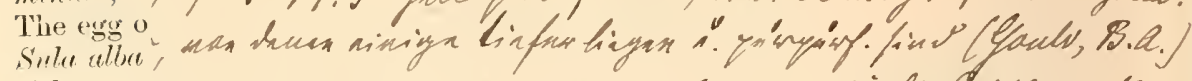

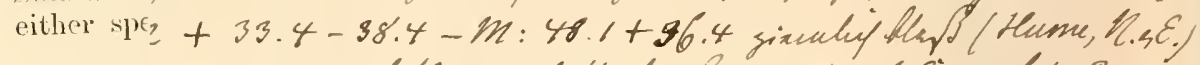

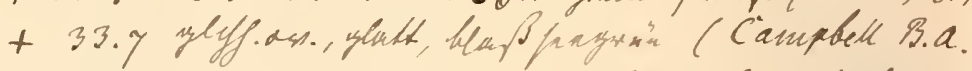

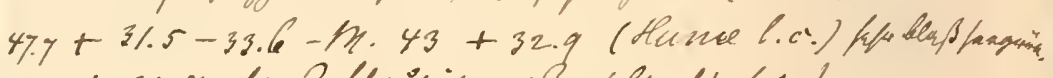
In $N .5+31 . y$ beap blaingij maip (qrald. 1.0.)

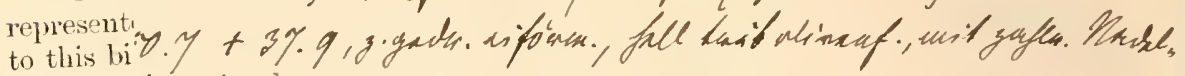
hawk; "Lell l.c.)

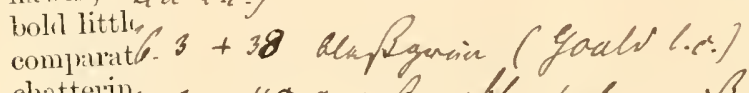

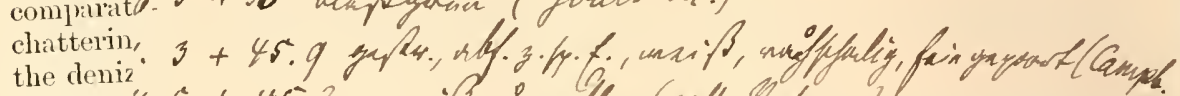

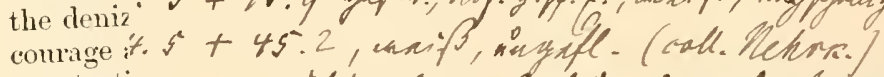

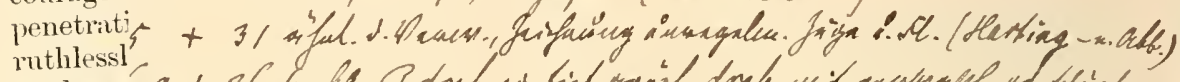

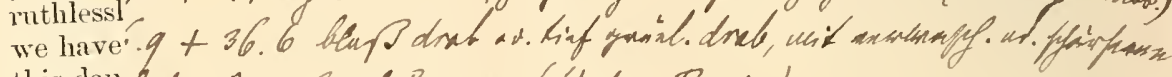

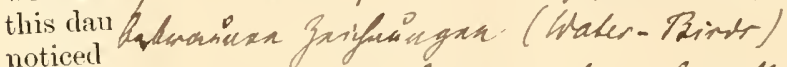

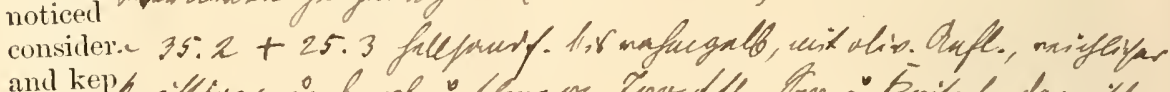

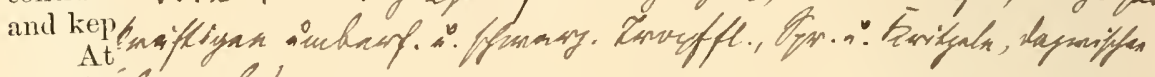
breediự Cample.)

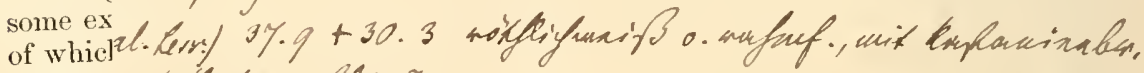
Pigeon. / Hechera, Basis 70.

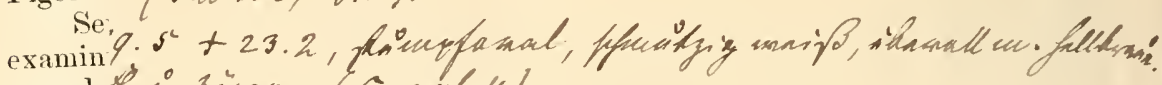
regards $\psi$. $\therefore$. Jiogan. (Camphele)

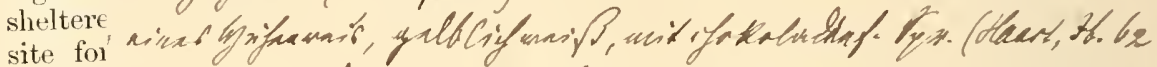
pereyrit $+3 q$, usin ding: cakl m., Eherk.)

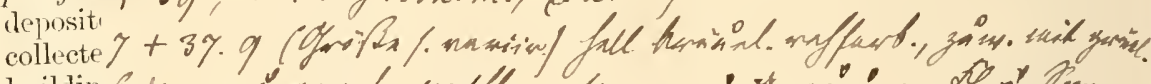

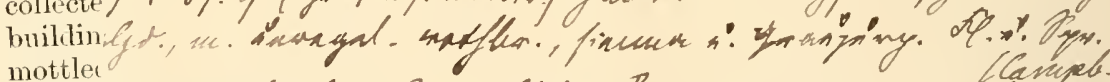

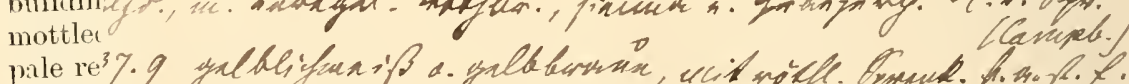

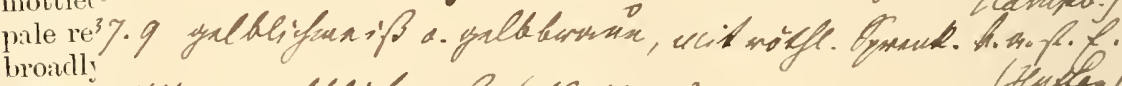

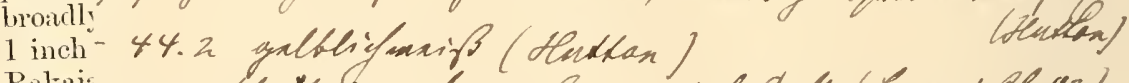

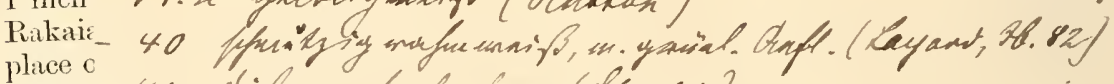

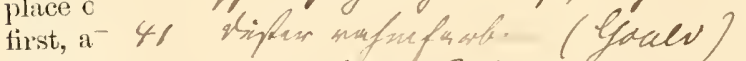

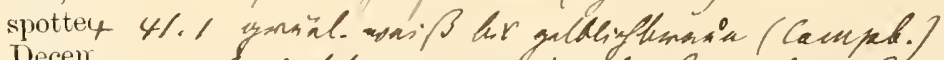

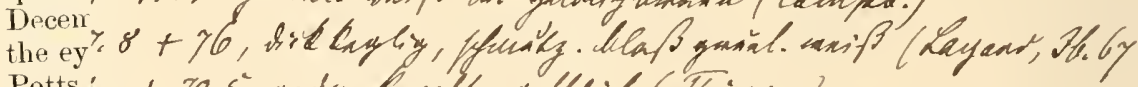
Potts.: + $79.5^{2}$ yadm. Lagalf. yalbiy (Minem.)

Rangi

foumd

young

young 
No. 2.-Circus Assimitis, Jard.

Kahu.

Harrier.

One of the commonest of the larger birds met with on "the plains." From its depredations on poultry of all kiuls, game, etc., great numbers of this fine Harrier are annually destroyed by means of the gun, poison, or the trap. Over a lambing flock it may be frequently noticed soaring with wide circling flight. On a weakly lamb its attack commences by picking out the eyes. Birds it carefully plucks before it begins its meal. It is not an unusual occurrence to find it with a young Happer, almost as neatly plucked as though the work had been performed by the skilful hand of a poulterer. We found, on one occasion, a good sizerl Shag which had been thus operated upon; this was in winter time (July), and shows it has sufficient strength and courage to attack and destroy a bird of coissiderable size and power. Its favourite building-place appears to be a low-lying situation amongst swamps, the margins of lagoons, etc. The nest, built on the ground, is made of coarse grasses, such as tohe-tohe, raised sometimes about a foot in height, rather flat on the top. We have found it partly constructed with pieces of the thorny Discaria, and the dead flower-stems of the large Aciphylla, above which prickly nuaterials grass has been carefully placed. The eggs, usually four in number, are white; when perforated, and held against the light, the interior shows a deep green ; length, 1 inch 11 lines, with a breadth of 1 inch 6 lines.

A pair of these birls marle use of the same nesting-place year after year, amongst some strong tohe-tohe, close to the Ashburton River. We took fiom this nest an egg, which had been entirely covered up with the mater ials which had been brought to renovate the nest, at a period, subsequent to the breeling time, at which this egg had been lail.

From our memoranda, the months of November and December appear to be the height of the breeding season; it is found moulting in February ; occasionally fine old specimens are met with, in whish the whole plumage has assumerl quite a light tone of colour; this is so conspicuous in some individuals, that some collectors endeavour to persuade themselves that a new species has been discovered. Perhaps the noiseless flight of this birl should be noted. When swooping on its quarry, the clean long tarsi enalle the observer to see the action of the feet, the rapid contraction and expmision of the toes, when striking at its prey ; should this prove too large, or too heary, to be swooped off at once, the Harrier will drag it a considerable distance, apparently changing its hold frequently, accompanied with much noiseless fluttering of the wings, each time it strikes out its sharply armed foot to obtain a fresh grasp. To give some idea of the numbers of this hawk that are amnually destroyed, it may be mentioned, that on the Cheviot Hills station, ten to twelve per day were frequently killed, and that it would be within compass to reckon that mpards of 1,000 lawks per annum haul been thus accounted for during the last two or three years; amongst these were a few of the Fralco $Y . Z$. It will not. ereate surprise to learn, that on this rm rats are most abmelant. On a farm on the Halswell, as many as tifteen were found poisoned in one morning. On another form in this neighbourhood, numbers have been trapped by the use of a common rat-gin fixed on the top of a $\mathrm{Ti}$ palm.

\section{No. 7.-Hahcyon vagans, Giay. \\ Kotare. \\ Kingtisher.}

One of our burrowing species. The tumnel-like hole, which forms the approach to its nest, is fommd sometimes in a bank, and. perhaps, quite as often 
in a tree. On examining one of these holes, in a bank not far from the sea beach, the floor or hottom was olsserved to incline slightly upwarls from the entrance, the eggs, lleposited on the remains of crustaceie, were not more than one foot back from the outside of the hole. When a tree has been selected for its home, we have been led sometimes to the discovery, by observing the quantity of chips lying beneath; its powerful bill soon excavates a nestingplace in the partially decayed wood. The situation varies from a few feet to above thirty feet from the ground (See Plate 4, Figr. 1). The eggs are pure glossy-white, delicate, and very beautiful, more fragile, perhaps, than those of most other species, oval in shape, with a length of $l$ inch $\frac{1}{2}$ line, by a brearth of $10 \frac{1}{2}$ lines. After hatching, the nest is carefully eleared of the broken shells. The young remain in the nest till well-Hedged, and, apparently, almost fullgrown. On eximining the castings of the Kingfisher, which are often to be met with in abundance near a nest containing young, we have observed that the external wing-cases of coleopter:e, have formed one of the principal ingredients of the pellets. We have noted that a nest from which the young emerged late in November, again contained eggs in January. Onr Halcyon must lay a much smaller number of eggs than the English Kingfisher. Althongh this bird may be constantly seen occupying some prominent branch, or stake, when watching for its prey (which, by the way, is of a very miscellaneous character), yet, when approaching or leaving its nest, it always, where possible, seeks the screen of overhanging trees, as it swiftly darts through the gully, permitting but a glimpse of its bright showy feathers. Should any one approach too close to the neighbourhood of its breeding-hole, the parent bird utter's a low cry, like cree, cree, cree, frequently repeated. Our bird is much more sociable than its European relative, which is so remarkable for its solitary habits, that it has been stated, that the male and female only associate togrether at the breeding season : we have counted as many as eight of our Kingfishers sitting in company; after a heavy rain we have observed, on our lawn, several of the eroquet hoops oceupied at one time by these strikinglooking birds. It is rarely to be seen on the ground; after darting down, either in the water, or on land, and securing its booty, it immediately flies with it to some perch, or post of rantage, and prepares it for deglutition, by arlministering some smart blows with its bill, the sound of which may often be distinctly heard. During the breeding season it judnlges in a monotonons call of ehimp, chimp, chimp, then a pause, the call and panse alternating for a considerable time. Fish, erustacer, young linds, mice, coleoptera, bees, and other insects, furnish some portion of the food-supply of the Kingfisher ; we have often noticel its rapid dart at a brood of young ehiekens. This bird is one of those fortunate species, whose numbers seem rather to increase than diminish at the approach of civilization.

The name of Halcyon given by ornithologists to this species, carries us far back into the very early days of Natural Mistory. 'The history of its European congener was enveloped in poetic fables for centuries; probably no other birl, whose habits could be so easily ouserved, has been so universally the subject of groundless tales, or superstitions regard,-perhaps the recital of some of these notices may be excuserl. Aristotle, after a fair description of the birl, gravely states: "Its nest resembles the marine balls which are called hechosachure, except in colour, for they are red; in form it resembles those sicyie (cuculbits) which have long necks." Again, he says: "This bird hatches its young about the time of the winter solstice. Whereupon fine days occurring it this season are called Halcyon days." Omitting the fabulous accounts of many ancient authors, let us peruse the account of the philosopher of a more recent date, on the breeding lrabits of this wonderful bird; thus quaintly wrote Montaigne:- 
"Mais ce que l'experience apprend à cenx qui royagcnt par mer et notamment en la mer de Sicile, de la condition des halcyons, smipasse toute humaine cogitation. De quelle espece d'animanx a jamais Nature tant honoré les couches, la naissance, et l'enfantement? car les Poëtes disent bien qu'une seule isle de Delos, estant auparavant vagante, fut affermie, pour le service de l'enfantement de Latone: mais Dien a voulu que toute la mer fut arrestée, affermie, et applanie, sans vagues, sans vents, et sans plnye, cependant que l'halcyon fait ses petits, qui est justement environ le Solstice, le plus court jour de l'an: et par son privilege nous avons sept jours et sept nuicts, an fin coen de l'hyver que nous ponvons naviguer sans danger. Leur femelles ne recognoissent autre masle que le leur propre: l'assistant toute leur vie sans jamais l'ábandomner: s'il vient à estre debile et cassé, elles le chargent sur leurs espaules, le portent partout, et le servent jusques à la mort.

"Mais aucune suffisance n'a encore peu atteindre à la cognoissance de cette merveillense fabrique, dequoy l'halcyon compose le nid pour ses petits, ny en deviner la matiere. Plutarque, qui en a veu et minié plusieurs, pense que ce soit des arestes de quelque poisson qu'elle conjoinct et lie ensemble, les entrelassent les unes de long les autres de travers, et adjoustant des courbes et des a rondissemens, tellement qu'enfin elle en forme un vaissean rond prest à voguer: puis quand elle a parachevé de le construire, elle le porte au batement du flot marin, là où la mer le battant tout doncement, luy enseigne à redouber ce qui n'est pas bien lié, et à mieux fortifier aux endroits où elle void que sa structure se desment, et se lasche pour les coups de mer; et an contraire ce qui est bien joinct, le batement de la mer le vous estreinct, et vous le serre de sorte, qu'il ne se peut ny rompre ny dissoudre, ou endommager à coups de pierre, ny de fer, si ce n'est à toute peine. Et ce qui plus est à admirer, c'est la proportion et figure de la concavité du dedans: car elle est composée et proportionée de maniere qu'elle ne peut recevoir ny admettre autre chose, que l'oiseau qui l'a bastie : car à toute antre chose, elle est impenetrable, close et fermée, tellement qu'il ny peut rien entrer, nou pas l'eau de la mer senlement. Voyla une description bien claire de ce bastiment et empruntée de bon lieu : toutesfois il me semble qu'elle ne nous esclaircit pas encor suffisamment la difỉculté de cette architecture. Or de quelle vanité nous peut il partir, de loger au dessous de nous, et d'interpreter desdaigneusement les effects que nous ne pouvons imiter ny comprendre?"

Sir Thomas Browne, the exposer of vulgar errors, in his "Pseurlodoxia Epidemica," after stating the results of actual experiments, which enabled him to contradict the common notion, that a Kingfisher, suspended by the bill, would show from what quarter the wind blew, yet, apparently, received the ancient fable of the halcyon days without any distrust, for thus he wrote concerning the peculiar relations existing between this lird and the winds :"More especially remarkable in the time of their nidulation and bringing forth their young. For at that time, which happeneth about the brumal solstice, it hath been observed, even unto a proverb, that the sea is calm, and the winds do cease, till the young ones are excluded, and forsake their nest, which floateth upon the sea, and by the roughness of the winds, might otherwise be overwhelmed. But how far hereby to magnify their prediction we have no certain rule; for whether out of any particular pre-notion they choose to sit at this time, or whether it be thus contrived by concurrence of causes, and providonce of nature, securing every species in their production, is not yet determined." It would occupy too much space to mention the names of naturalists and writer's who adopted similar romantic tales, each of whoru was, of course, supposed to be narrating a particular and reracions accomnt of the extraordinary mode of nidification of the Halcyon. Mr. Gould dissipated, 
at last, whatever might have remained of these clouds of fable, by depositing the nest, entire, in the British 11 useum; a feat, the difficulties attending which were so well appreciated by all bird-nesters, that there was a report, or tradition, throughout many parts of England, that the authorities of the British Musemm had offered a reward of $£ 100$ for a perfect nest of the Kingfisher. For a full account of Mr. Gould's exploit, see "Homes without Hands."

Shakespeare, in "King Lear," and several other" writers, allude to the superstitious idea, that, if suspended by a thread from the ceiling, with windows and doors closed, the Kingfisher would turn its bill towards the quarter from whence the wind blew.

Amongst numerous other virtues, it was supposed to be a protection against thunder, against the ravages of the moth in woollen clotll, to be able to increase hiclden treasure, to bestow grace and beanty on the person who carried it, and enjoyed the power of renewing its plumage, after death, by moulting.

\section{No. 10.- Prosthemadera Nove Zelandie, Gml. \\ Tui. \\ Par'son-bird.}

We have but seldom found the nest of this very common bird, whose varied notes break upon the stillness of the bush. Wherever we have met with its nest, it has been lather on the outskirts than in the depth of the bush itself. The Parson-bird seems thoroughly joyous only in the full glow of sunlight, where it may be seen in numbers, darting upwards far above the highest trees, and revelling in its free stretch of wing, now and then playfully pursuing some smaller bird, till it seeks the shelter of a friendly bush.

We have found the nest from twelve to thirty feet from the ground, and have noticed that whether against a White pine, or Black birch, there has been a sheltering cluster of Rubus, with its sharp, recurved prickles, beneath which the structure has been concealed. We have found it more than once near the top of a Myrsine Urvillei, over which the Rubus has thrown its straggling cords, forming a prickly canopy most difficult to penetrate. The nest, rather large, made of slender sprays intermixed with moss, and the wool or down of Treeferns (Cyathea dealbata), lined with fine bents of Poa giass; the dimensions we noted of a nest are as follows: across the top, from outside of wall to outside of wall, 9 inches, diameter of cavity, 3 inches 6 lines, with a depth of 2 inches. The eggs, usually three or fom in number, are white, or with the slightest tinge of pink, marbled with rust-red veins, most unmerous towards the larger end, rather pyriform in shape, they measure 1 inch 2 lines in length, by 10 lines in breadth. The nest containing young is sometimes stained deep purple, from the juice of the Konini berries (Fuchsia excorticata). On one occasion, the young, unable to fly, on being alarmed fluttered ont of the nest to the ground, at fall of about twelve feet, the next day they were found safely ensconced within the nest, looking quite hatpy; this conld only have been effected through the assistance of the parent birds. The Tui is rather combative whilst the young require feeding, even when they can fly well, it may be observed driving away the Kingfisher and Bell-bird from the trees in which its young are lodged. However much the white-tufted Tui may add to the interest of our forest scenery by the beauty of its glossy plumage, the gaiety which distinguishes its flight, or the wild ontburst of its joyful notes, in the eyes of the onmivorous settler, it possesses the higher merit of furnishing a savoury article of food, and no weak sentimental feeling saves it from the camp-oven. It is frequently kept in confinement, and at one time many were sent to the neighbouring colonies. (See Plate 6, Fig. 1). 


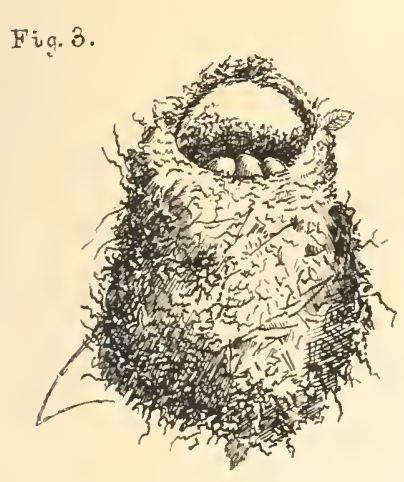

$\ll-4$ inches $>$

\section{Neszs uf}

PETROICA MACROCEPHELA.

Fig. 7.

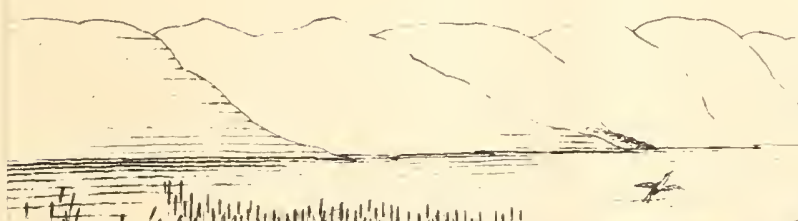

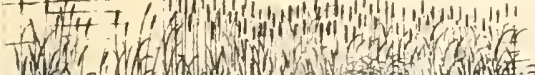

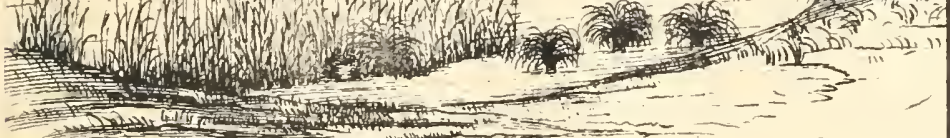

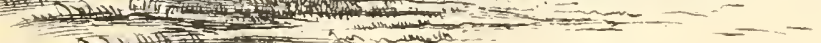

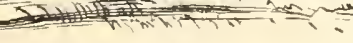

Nesz of

BOTAURUS POICILOPTERUS.

Bibzisin. 

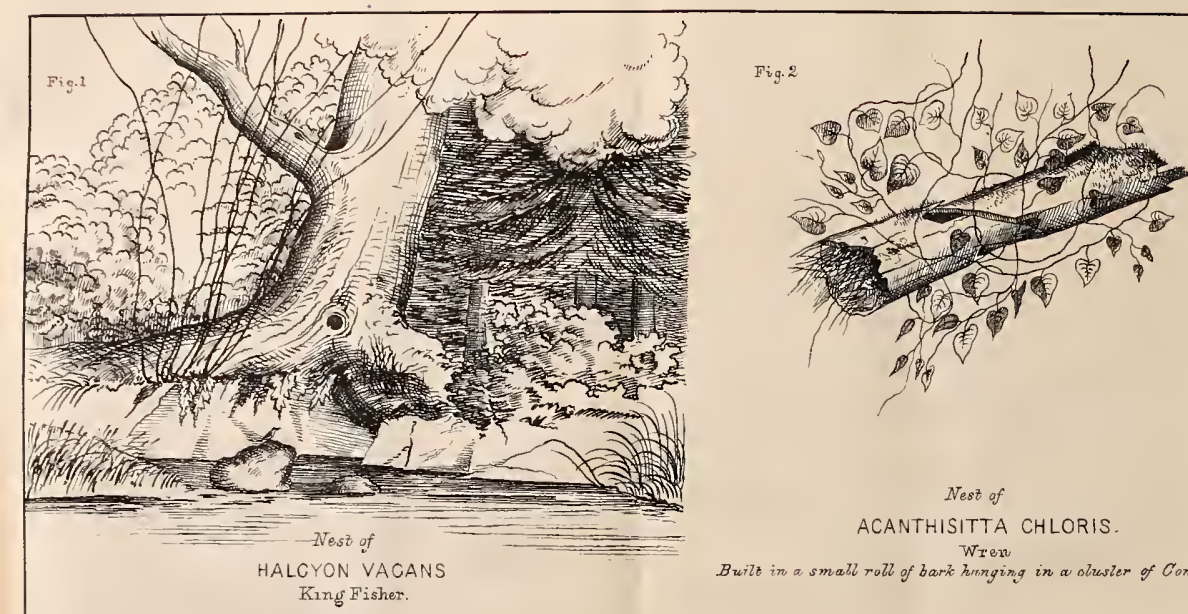

Nest of

ACANTHISITTA CHLORIS

Buile in a small roll of bark hringing in a sbuster of Convabuulus

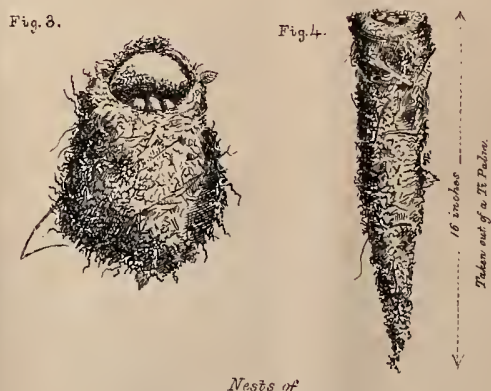

PETROICA MACROCEPHELA.

Fig. 5 .

$F i, 6$.

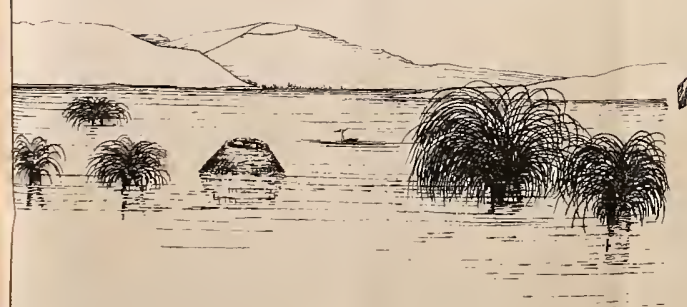

Nes* of

PODICEPS HECTORI

Nesz of

Grebe. On a fromd of ins sibver tros fern Cyathea dealbata

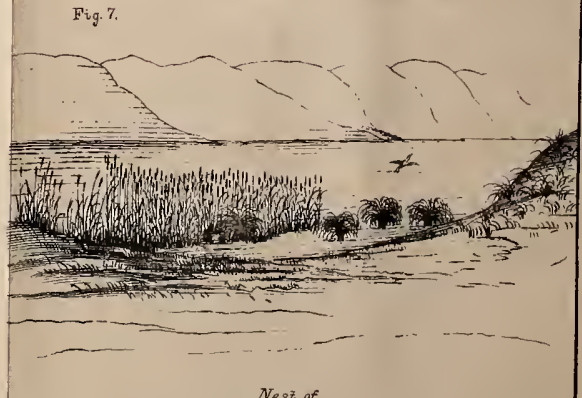

BOTAURUS POICILOPTERUS. 
No. 11.-Anthoris melanuRa, Spal'rm.

Koromako.

Bell-birel.

Everyone who has rambler throngh the bush, or even strayed amongst the shrubby thickets that finge our numerous gullies, must bave become familiar with the clear metallic ring of the Bell-bird's note. It may be said to sing matins and vespers for the warbler's of the bush, as it is at the grey break of dawn, ancl the still honr that closes in the day, that its chime strikes clearest on the ear. It is comparatively silent during the noonticle heat, unless some few indiriduals meet on a tree or shrub, that offers a tempting show of honey-bearing blossoms, a note or two is briefly sounded, the number's rapidly increase; after much noisy Huttering of wings, a gush of clanging melocly lnussts forth from a score of quivering throats, forming a concert of inharmonions, yet most pleasing sounds. Probably Cook indicated the Bell-bint, then in a comparatively unmolested state, when he wrote, "the ship lay at the distance of somewhat less than a rmarter of a mile from the shore, and in the morning we were awakened by the singing of the birds; the number was incredible, and they seemed to strin their throats in emulation of each other. This wild nelody was intinitely superior to any that we had ever heard of the same kind; it seemed to be like small bells, most exquisitely tuned, and perhajs the distance and the water between, might be of no small arlvantage to the sound." Nor does this cheerful bird confine itself to the busli, it frequents our gardens and shrubberies, and especially affects the blossoms of the Fuchsia, Tritonia, Acacia, etc. The lempies of varions Coprosmas, and that of the Konini, it greedily devoms ; it may be frernently observed fluttering heavily in pursuit of a moth. It is very easily snared with a noose at the end of a tohe reed ; in confinement it feerls on soaked bread, etc. Whilst the Phormium tenax is in blossom, many Bell-birds may be observed with their hoad featliers dyed orange-red, from contact with the pollen and honey, whilst extracting a delicions rejast from the flax blooms. It has been stated that zealons ornithologists have deemed the bird thus decorated, a new species.

Placed at no great elevation from the chromel, the nest may he foumd in a variety of positions, but we certainly latve noticenl it most fierpuently beneath a sheltering canopy of "Bush-lawyer" (Kubus unstrulis.) It is rathen flat, and loosely construeted of sprays, grass, moss, ete., well linerl with featlurss. On examining the fommlation of a nest, we fouml grem sprays of 1 ammka amongst the interlaced materials, a fact which clisclosed the proof of the power of the bill of this loney-sucker in breaking off such tongh twigs. From wall to wall, across the top, the nest measures ahout 5 inches, diameter of carity, 2) inches 9 lines, depth inside, about 2 inches. We fancy that the lining feathers ate selected in such a manner as to afford some evidence of harmony of "olum in their arrangement; as, for instance, we have noterl specimens, with the inner lining entirely composed of the red feathers of the Kaka, another anlorned with the green feathers of the Parroquet; near the farm, where many kinds of poultry are kept, we have had instances of lining, white, blark, specklent, hutf, etc., but nuiformity of colour las heen risplinyed. The eggs, four in number; are white with reddish specks, sometimes the ground-colonr exlibits a delicate pinkish tinge; they measnre in length 11 lines, with a breath of $8 \cdot \frac{1}{2}$ lines. We must lave peered into scores of nests. in varions parts of the comntry, hut we have never yet been fortunate enough to encomiter such a prize as one containing "seven eggs, spotted with blue, upon a hrown ground," ascribed to this bird by the Rer. R. Taylor, in his work "Te Ika a Mani." The breedingseason extends from the enmmencement of spring, throughnt the summer 
montlss. We have discovered the nest in an old flower-branch of the Ti palm (Cordyline australis). (See Plate 5, Fig. 1.)

Noте.-Feb. 2, 1868 - Bell-bird buikling; that would give the breeding season a duration of about six months.

\section{No. 15.-Pogonornis cincta, Dulus.}

A nest, assigned to this bird, was found in the bush above the Kaiwanawark stream, not tar from Wellington; it contained one egg, rather oval in form, sonewhit pointed at eitch ent, measming 9 lincs in length, with a breadth of 7 lines; the whole surface clonded over with pale rufous-brown.

The nest, with thin walls, and of shallow form, was built of spratys, above which were laid fibres and dry rootlets of Tree-ferm ; fine grass was used for the lining, over which cow-hair was haid, and measured, across the top, 4 inches 9 lines, cuvity 2 inches + lines, depth 1 inch + lines. This description is from the specimen in the Colonial Museum, WVellington.

$$
\begin{gathered}
\text { No. 18.- } \\
\text { Pi waill wall. } \\
\text { Wien. }
\end{gathered}
$$

This, the smallest of our birds, is usmally seen in pairs, flying low, with a fieble, jerky style of tlight; more frequently it is mot with creepling annongst the lichons and mosses that rlecorate the stems and branches of our forest trees. We have foumd the nest in a small hole in the tromk of a Fagns. Once a nest was discovered, very cleverly built in a roll of bark, that humg suspended in a thicket of climbing Convolvulus. (See Plate 4, Fig. 2).

The eggs are said to be very numerous sonetimes, althongh four or five lave been the most we have olserved to a nest; like those of nearly all troglorlytal birds, they are white and glossy ; oroiconically shaped, they measure $7{ }_{4}$ lines in length, by 6 lines broad. We have a note of the Wren breeding in August.

\section{No. 19.-Mohoua ochrocephala, Gml. \\ Mohoni. \\ Canary.}

Althongh we have not observed this birl anywhere on "the plains," or" on the lower" ground of the "lays," yet as soon as one ascends the bushy gullies of the hills, the Canary is sure to pny a reconnoitering visit; with sliarp strilent call, it summons its comprnions, and the trees around will soon disclose the golden breasts and heads of these active arboreals, as they peer down on the intruder with noisy clamour. With restless morements, they creep roumd, above, and below the leafy branches, in their insect seareh. We have watehed them on the groumd, busily seratching and peeking between the huge moss-clothed roots of the lofty trees that tower above. The nest measming across the top, 3 inches 3 lines, with a depth of 1 inch 4 lines, is a beantifully compact structure, cup-shajed, principully of moss, very closely felted, and neatly interwoven with webs of spicters. (See Plate 5, Fig. 2). In the hollow trunk of the Broad-leaf, it is sometimes foumd, and occisionally in a decaying Black Birch. Eggs white, with very small faint specks of red, neirly 11 lines in length, with a irearth of $8 \frac{1}{2}$ lines. We have a specimen of the nest and eggrs from the River Vilberforce.

\section{No, 20.-Sphencacus Punctatus, Quoy, and Gaim. Mata. \\ Grass-lird, Grass-pheasant, Utick.}

Some years ago the monotonous note of this little birt might he heard in almost any flace, where tall tolne-tohe reeds, or the waving learses of the farex 
virguta, indicated marshy ground; now it is rapidly disapporing, as the swamps are broming drained. As its very feeble power of Hight is unatule to save it fiom the bush fires, we anticipate it must beome extinct, on "the plains," at no very distant date. From its call, it is in some places named the Utick. The nest, inclining somewhat to an oval shipe, and measuring abont three inches across, is marle of grass leaves, so fratil in its construction, that the walls may be seen through, conseruently it is a tifincult specimen to obtain in at porfect state (See Plite 5, Fig. 4); a few feathers, nsually those of the P'ukeko, are adderl to the grass leaves, and sometimes a smiall tuft or two of wool. The siturtion is, most frequently, in a tussock, a few inches abore the level of the giound. The eggs. three or four in mumber, are white, speckled with a beantiful tint of reddish-pmple, which at once readily distingnishes them firm those of any other bird ; oroiconical in form, they measure, through the axis, 10 lines, with a cliameter of $7 \frac{3}{4}$ lines.

Notes.-Nor. 4-Nest containing three young birls, in a tussock, at the edge of a wicle creek.

Nov. T-Nest with four eggs, in a swamp by the Horolatat stream, in the Malvern Hills.

\section{No. 25.-Gerygone assiulds, Buller: Piripiri. \\ Warbler, Teetotum.}

This cheerful little warbler is a pensile nest-builder, and one of the earliest hieeders; its neat, domed nest may be often fouml, in Augnst, suspended in some bushy Manuka or Olearia. The nest may he called somewhat pear-shaped, with a small entrance near the middle, above which is often affixed a kind of porch (See Plate 6, Fig. 3), it is suspended by its toj', and kept steacly from swaying in the breeze, by slight fistenings to a spray or two, acting as guys. Moss enters litrgely into its construction, very frequently wool ; we have examined one, the greater part of which was composed of wool; coljwebs are freely made use of, to felt and bind the materials into a compact mass. We have a nest before us, taken from the fork of a Willow tree, at least twentyfive feet from the ground ; it is rather larger than usual, and almost wholly constructer of poultry feathers and cobwebs. and is felterl into a compact, firm strneture, the porch and its foundation, beneatl the entrance, is strengthened and kept in shippe by fine roots carefully interworen with green cobwelss; here and there may be foimd pieces of thread, string, colomred worsted, pickerl "1 from the garden or yard ; the interior is thickly linerl with feathers (See Plate 6, Fig. 2), this nest is evicently composed of materials, which wonld not have been made use of so freely, lut for its firm and sheltered position in the fork of the willow, the most exirosed part only being strengthened with stiff material.

Sometimes, yet rarely, the nest is built in a less elaborate manner, withont either done or porch, the form of the strmeture being actapted to the peenliarities of the situation chosen; the principle of suspension is likewise oceasionally abandoned. Five or six eggs are usually fouml to a nest, they are white, with reel spots, ovoiconical in shape, 8 lines in length, with ir breadth of 6 lines. No birl suffers so frequently from the imposition of the golden-winged Cuckoo, as the grey Warblel: We have several times observed a pair of these inchustrious little insect-eaters, feeding a young parasite larger. than themselves. The Cnckoo only artives in Oetober, when the wamntl of Spring is well established ; and one reason for the selection of the Warbler's home, in aclition to its pencile character, appears to us to he, becuse from its shape and structure it is the warmest nest, to be fomml, for rearing so tender at birl as the Chrysococeyx, our gay visitor, during the spring and smmmer months. 
Note.- We have found eggs of the Warbler quite white, doubtless the produce of young birds. As yet we have failed to observe any such distinctive features, either in the structure or habits of these Warblers, that they should be classed as separate species, under the names of flavicentris and assimilis. We alhere to assimilis, as is adopted in the collection in the Canterbury Museum.

\section{No. 26.-Certhiparus Nova Zelande, Gml. Brown Creeper; Brown Canary.}

Althongh this Creeper may be seen in ahmost every bush, from the coast to the clistant Alpine Ranges, we have only once found its nest. This was in the month of December, far above the Rangitata Gorge. The nest, containing three young lirrls, was compactly built of moss, with a few feathers, placed in a Black-birch, between the trumk and a sprur, from whence sprouted ont a thick tuft of awirfish sprays, alont seven feet from the ground.

\section{No. 27.-Certhiparus albicilla, Less. Mohona.}

This hird appears sufficiently common, abont the bush ahove Wellington, for its habits to be well studied. There are several specinens of the nest and egres in the Colonial Museum, Wellington. The nest is a very compact structure, having very thick walls, and in its style of architecture hears a strong resemblance to that of $M$. Ochrocephalo, although, in some instances, different materials are nsed. In the one before us, different kinds of soft grass and moss form the staple, well-felted and interwoven with webs, lichens, and the down of tree-ferns; it measures 4 inches 1 line across the top, cavity 1 inch 10 lines in diameter, 1 inch 4 lines deep. Eggs white, or with very faint speeks of pink, measure $10 \frac{1}{2}$ lines in length, with a breadth of $7 \frac{1}{2}$ lines.

\section{No. 29.-Petroica macrocephald, Gml. Ngirungiru. Piro piro. \\ Tontit.}

This familiar little birl is one of the more elaborate nest-builders amongst the lenizens of the hush, or rather its outskirts.

It adlupts itself, in a mammer, to civilization, frequenting gartens, and may be seen perched on a bough, really to pounce on the grubs the gardener's spade may bring to light, reminding one very mnch of the habits of the Red-breast at home.

The nest varies much in shape according to position ; frequently we have found it in holes of trees; a favourite site is immediately mniler the head of the ti tree (Comdyline anstralis). Two nests we presented to the Canterbury Musemm, were of remarkable shape ; one, a firm compact structure, placed in the forked hearl of a ti tree, resembled a very neat moss basket, with a handle across the top; the second, also from a ti tree, from, perhaps, the foundation slipping between the leaves, was bnilt up till it reached the great length. of sixteen inches. (See Plate 4, Fig. 4). We have found others placed on a rock, and one, now in the Colonial Musenm, was built between the brace and shingles in the roof of an empty cottage.

The nest is neatly and firmly built of a variety of mater ials, carefully and neatly interwoven; moss, grass-bents, stender sprays, the down or wool of the tree-fern, cobwebs, and feathers, warmly line the interior. Four eggs is the risual number lind, though we have been told of more having been found; they are white, with grey speckles, most numerous towards the larger end, 9 lines long and 7 lines broad. A nest built in a ti tree, close to a pathway, 
was almost daily visited by the child who had made the discorery, and the eggs inspected; when hatched the young were now and then handled, yet the confidence of the old birds carried them through this trying ordeal, and their young ones were snccessfully reared.

This is one of the few birds, of whose extinction we are happy to believe there is no dlanger; it is most useful as an insect rater, it is one of the latest to retire to rest, and may be often observed perched on the trmnk of a tree, in a posture by which its body is almost at a right angle with the tree. The nests, described above, were found abont Ohinitahi, where bircts are as much encouraged, and as little disturbed as possible. Last summer another specimen was noticer, which har been built upon an old nest, making a solid mossy structure, measuring about one foot from top to bottom. The usual dimensions of the nest are as follows:-Across fiom outsicle of wall to outsicle, 5 inches; carity 2 inches 6 lines, with a depth of 1 inch 6 lines.

\section{No. 31.-Petrolca tortor, Less and Garn. Tit.}

Whatever distinguishing features, scientific research may have discovered, which allows specific differences between $I$. Dioffenbrechi and $P$. toitoi, we fral they are not generally appreciated or understooil. Perhals this may he a fair opportunity of pointing out that the nomenclature of our birds still requires attention, and, above all, settlement; to the enquiring stulent of ornithology, scarcely anything can exceed the perplexity and embarrassment which is caused by a conflicting nomenchature. To give one instance: Aurrynchus firotalis appears in Dieffenbach's list; since then we have noticed it as Charadrius, Hamatopus, and now Anarynchus once more. Let ns hope this may be the last change. We have often observed a Petroica, whose favourite haunt appeared to be amongst large areas of flax hushes (Phormium temax), but confess we conkl not undertake to decile to which of the two species, named above, the Tit, to which we have referred, belonged; nor is there, unfortunately, any complete type collection, either in Wellington or Christchurch, which could decile any doubt that might be entertained on the subject. We have a set of eggs in our collection, which we are inclined to assign to the $P$. toitoi; they are slightly more inclined to pyriform, in shape, than those of $P$. Macroceplualce, white, with marks of purplish-grey towarls the larger end. and measure 9 lines in length, with a brealth of 7 lines.

\section{No. 32.-Petroica longires, Less. and Garn. Robin.}

In the Colonial Musem, Wellington, there is a specimen of the nest and eggs of this bird.

The nest, compactly built of moss, fine roots, web, and tree-fern down, is more neatly finished than that of $P$. albifions. The eggs, ovoiconical in form, are marked, principally at the larger end, with specks of greyish-l,rown.

\section{No. 33.-Petroica albifrons, Giml. \\ Totoara. \\ Pobin.}

Our rather dirty-looking Robin is one of the swcetest warblers of the bush, bold and conficlent, its habits may be easily observed, as one rambles near the rocky sides of a forest stream. Its nest is wirler, and larger altogether, than that of Petroice macrocephala, but not so closely interwoven; moss, sprays, leaves, fine fibres, and grass, enter into its construetion. Diumeter of nest 5 to 6 inches, cavity 3 inches, with a depth of 1 inch 3 lines. A farourite 
sitnation appears to be behind such protuberances as are to bo fomel on the lume gnarled tronk of Griselinia litoralis, very often not more than three fert from the ground. Eggs, three or fom in umber, are dullish-white, with radhlish maks, principally at the larger end.

\section{No. 31.-Anthes Nore Zelanthe, Gml. \\ Pihoihoi. \\ Lark.}

This well-known bird appears to be eommon all orer the country; it huilds on the gromel, making its nest of grass, usually sereened by a tussock. The eggs, five in number, are greyish-white, speckled orer with dark-grey; sometines a set of eggs may be noticed very much mottled over with brown, oroiconical in form, measuring $10 \frac{1}{2}$ lines in length, by a brealth of 8 lines. We have an egg, very much smaller and darker than any others we have yet observed. In February, 1868, a pair made their nest within six inches of a shrubbery walk, and reared their young successfully, although so fiequently disturbed, - the old bird invariably quitted the nest on its being approached. When a Harrier wheels romd, and appears ahout to settle, larks may often be observed, in numbers, gathering together with a chirping note, moving restlessly, sometimes with a short flight, watching and following the movements of their enemy.

Probably it is attempting to rid itself from the persecution of some marisitic vermin, when this bird is frequently observed to indulge in a clustbath. It las a habit of keeping its insect prey in its beak for a long time, before it is devoured, or carried off to its nest. At last shearing time, two Larks, almost albinos, made their appearance, daily, about the yards of a wool-sherl, on the Waikerukini.

Note.-In Angust, a nest was brought to the Wellington Museum, which contained several tufts of moss, but not neatly interworen, like the workmanship of a birl that builds its nest pincipally of moss.

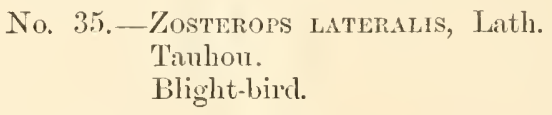

We first noticed this bird on some Fagus trees in the Rockwood Valley, Malvern Hills, July 28 th, 1856 . Its numliers, since then, have increased with great rapidity. It very soon obtained the name of the Blight-bird, in reeognition of its services to gardens and orchards, from its habit of feeding on the American blight, with which apple trees in this colony are so generally infested; but, although the gardener noticed with satisfaction its labours in this direetion, dnring the winter months, yet as summer returned and fruits ripened, its incessant depredations on cherries and plums were witnessed with anything lut pleasure. From examining scores of nests, we find that ont of a considerable variety of materials made use of, moss and grass predominate; the fabric is strong. although frequently slight, in some eases the walls are extremely thin ; it is usually suspended, at the sides, hy fastenings bound securely over slender twigs; some are almost wholly constructed of grass, amongst which, now and then, may be found a few small tufts of the grey-heard moss, in others the cottony down of plants is neatly interwoven witl moss and spiclers' webs, lined with fibres, or fine stems of grass, sometimes with hair; some nests are ruite shallow, others of deep cup-like form (See Plate 5, Fig. 3), and measure in diameter 3 inches, cavity 1 inch 6 lines to 2 inches, depth 10 lines to 2 inches. In gardens, it has been observed placed in a great variety of shrubs, occasionally in a rose-bush bordering a well-frequented walk; 
never far above the ground, usually from two to six feet. Whe have formd it suspended to our common fern, Pteris aquiliue. It lays three elear-blue egugs, ovoiconical in shape, measuring 8 lines in lengtl, with a breacth of 61 lines: incubation lasts about ten days. The nest and eggs form as pleasing an olject as those of the Hedge-sparrow at home. The gift of song does not appear to be equally shared by these birds; in addition to the quick, sliarp note or chinrup, which all seem to have in common, now and then an individual birel is heard pouring forth a low, well-sustained, melodious song; possibly the prower may exist in all adult males, only to be indulged in at paining time.

One of the pensile nest-builders, which seem to be almost equally riane in our temperate clime as they are in the old country. The suspension of its habitation is accomplished in a different manner from that of Gerygone, and more after the fashion adopted by Regulus cristatus, of Enrope, the Kinglet or Golden-crested Wren, except that the nest is rery often formed without any protection or shelter from an overhanging leaf. The rim of the ladle-shapred structure is firmly secured to a forked twig by silky threads of spiders' nests, finished on the outside, round the bottom, with brices of green leares of grass, crossed and recrossed, which auld much to the strength and stiffness of the fabric.

Now, as pensile nests are peculiarly adapted for ensuring the safety of their contents against the predatory attacks of various egg-robbers, does not the suspension of the habitation of the Zosterops, - the instinctive precaution of a foreign land (See Chrysococcyx lucidus), - afford an indication that it is a recent colonist, not yet so thoroughly acclimatized as to be fully aware of the immnnity it enjoys from ravages of snakes, etc. ? will that form of nest which is now sometimes found built in, rather than suspended from, a bush or thicket, become a more common object, and thus show a change in the style of architecture, as this bird, setson after season, experiences the comparative safety of the breeding-places in our cooler latitude? Amongst our indigenous genera are there any pensile nest-builders? For years we invariably foumd three eggs to be the complement to a nest; now this last season we have met with several instances where fonr eggs have been laikl, where this has occurred, the home has been built in, rather than fairly suspended from, a bush. If the reason, before suggested, for a modification in the munner of fixing the habitation be considered as not altogether too fanciful, may we not likewise be allowed to adrance our opinion that the change of climate is also gradually producing its effects in the increased fecundity of our little Blight-bircl.

Note.-Dec. 4-Nest in a manuka (Leptospermum scoporium), aplearexl to be completely lined and finished. On the $8 t h_{1}$ it contained thee egess; the next day a fourth egg was laid; on the 19th one callow nestling wats exhiliting its ugliness, perfeetly naked, except two or three small tufis of white down on the bald cranium, the body deep yellowish-pink, with dark slatey-colouresl marks along the line of the rertebre, the exterior of wing, amsl legs." The day following, his ugliness had a companion, on the $23 \mathrm{rr}$ feathers hat made the in appearance, where the slatey markings had been roticed ; two mhatcherl egres remained in the nest, which was only visited quietly once a diay.

Young birls, for some time after they en fly well, ean scircely he saill to possess any just pretension to the title of Zosterops, as they are withont the? circlet of white feathers round the eyes.

From the large number of nests we have olserred, December must be the height of the breeding season.

The Zosterops is so partial to the berries of the trailing Cotomerester mycropleylla, that we have known it to be taken by the hame, when it has luen busily engaged on them; in the early spring we have obserred it eating clover: 


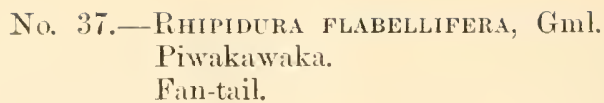

The pied Flycatcher seems to prefer proximity to water in selecting its nesting-place, we have noticed it most flequently near a creek, where overhanging boughs have afforded considerable shade.

The nest, beautifully marle, is very compact, and, from our experience, varies very slightly in shape. The materials are well felted together, moss, grassbents, fibrous roots, with cobwels, ete. ; the structure is fixed on some bough or spray, the foundation, very frequently, commences with chips of decayed wood. The prettiest nest we ever found, was on a leaf of the large silver treefer'n ( $C$. dealbutu.) (See Plate 4, Fig, 6.) The eggs, four in $n$ mber, generally are white with brown freckles towards the larger end, 8 lines long, by 6 lines broal. We never found the nest very early in the spring.

Towards autumn this bird frequents the verundah, enters the house, clearing the rooms of flies, the snapping of the mandibles is plainly heard, as it flits circling romul the room.

R. alliscapa, the fan-tail warbler of Tasmania, builds a nest with a long tail underneatl, giving the whole structure a funnel-like apperrance. Occusionally, R. Acabellifera also builds its home with a long tail, but broader and less artistically finished than that of the $R$. albiscapa. One nest in our collection has this peculiar appendage, constructed of skeleton leaves and bents of grass, etc. What is its use?

\section{No. 38.-Rhipidura fuliginosa, Spartm. Tiwaikawaka. Black Fan-tail.}

The Black Fan-tail Flycatcher breeds moler conditions so very similar to those of the preceding sprecies, that one description will serve for both. To our view, the most remarkable feature in the breeding habits of our Flycatchers is the situation usually selected for rearing their young. Security loes not apjear to be the first consideration ; security, by concealment, seems the leading feature which guides most arboreal birls in choosing the site for their home, and it is one in which the most admirable displays of instinct may be frecuently olserved. The Flycatchers rather apprear to be led by the same consideration which actuate many sea-birls in selecting the position of their breecling-place, proximity to the food sup]ly. Strull carefully along the rocky bed of a creek which rambles through some bushy gully, and you may perchance see the beantiful nest perched on some slender bough, in so delicate a manner, that it appears scarcely so much to be fixed, as to rest balanced there. There is no concealment amongst tangled creepers, guarded with their sharp recurved prickles; it is not buried amidst a mass of waving leaves, nor is it hidden away in the dim twilight of some hollow tree, but there, a few feet above the water, it sways gently with the subdued brecze, that reaches the quiet ravine through the leafy canopy that is spread around.

In thus placing its nest so obviously in view, one is reminted of its family connections, of the Spotted Flycatcher (1/uscicopre grisola) of the old comntry, which we used to terin the Post bird, from the almost glaing manner in which its unscreened halitation was displayed. But as "there is reason in the roasting of eggs," saith the proverb, so there is also instinct in selecting the place where they shall be laid ; orer the shady creek our Flycatcher is in the midst of sandflies, and the position chosen for its nest affords comparatively as good it vantage grounl for supplying the wants of its young, as the nestingplace on the craggy momntain side bestows on the dashing Quail-hawk. 


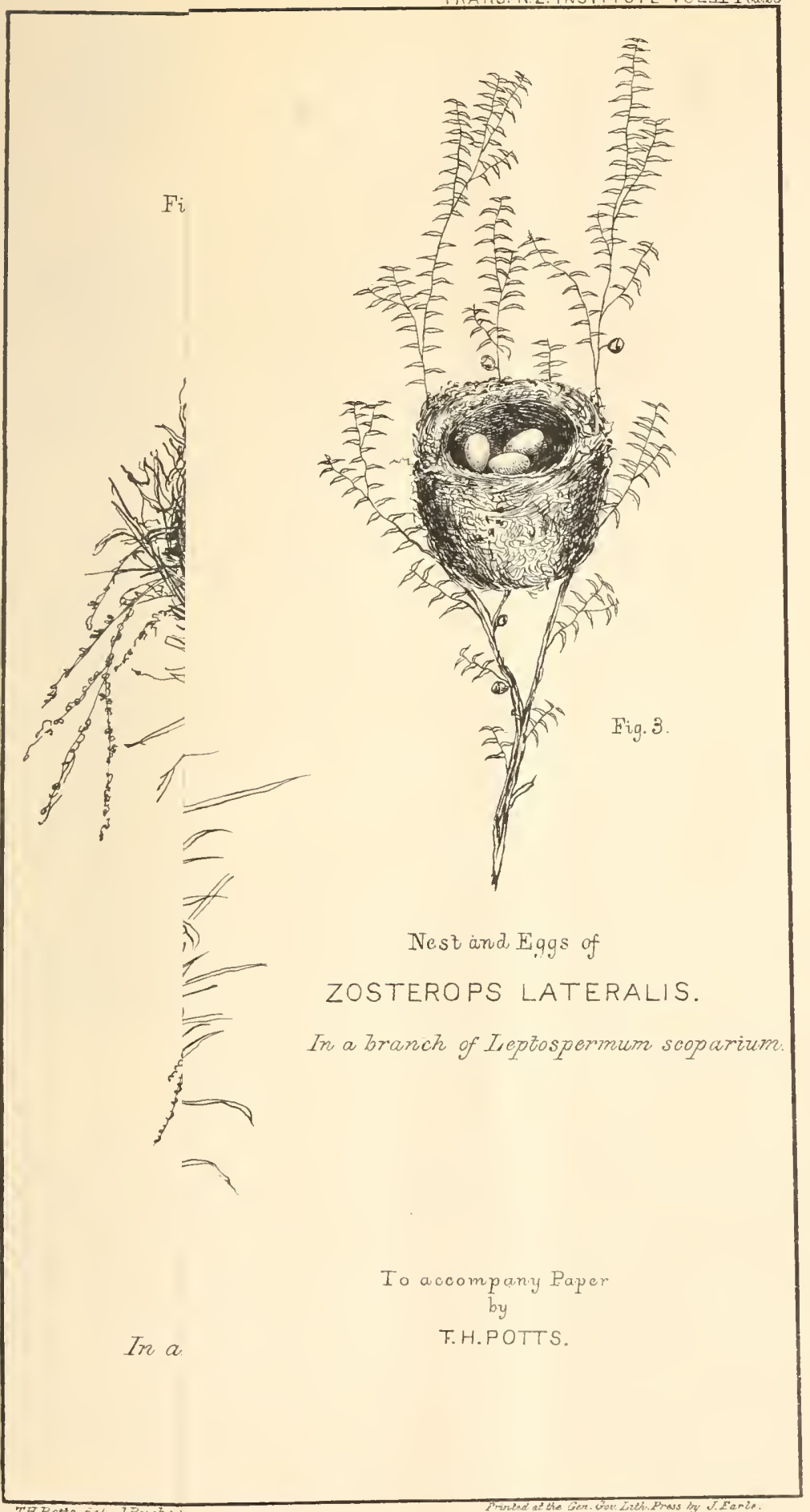




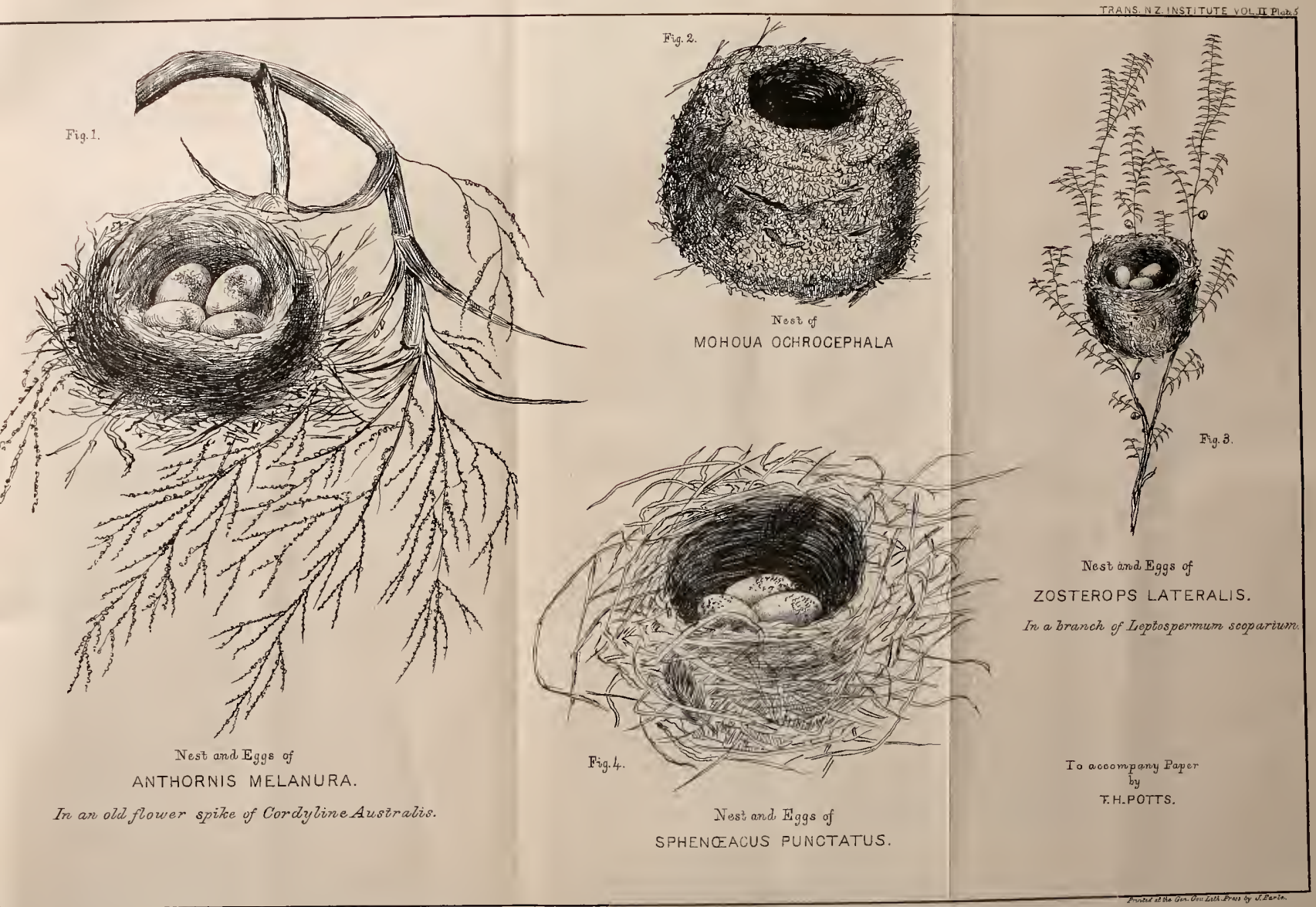


The Black and Pied Flycatchers hreed together frequently.

Note.-Dec. Sth-Nest and eggs of $R$. filliginosr fixed on a rock abutting on the creek in Valehead Bush, Malrern Hills; within a few feet, on the same rock, were two old nests.

\section{No. 47.-Platreerces Nove Zelandele, Sparm. Kakariki. \\ Parroyuet.}

As far as we are atvare, the breeding labits of this variety of Platycercus differ in no material point from those of ' $P$. auriceps. We have been told that occasionally it breeds on rocks. breadtl.

Eggs, oval in shape, measure 1 inch $1 \frac{1}{2}$ lines in lengtl, by 10 lines in

This species is frequently to be seen eager ; in confinement it imitates the human voice, with tolerable distinctness. This bird, as well as the smaller species, is frequently shot for foocl.

\section{No. 50.-Platycercus auriceps, Kulhl. Kakariki. \\ Parroguet.}

The smaller Parroquet is a beautiful object, as with merry note it darts across the forest glade, with its bright green plumage glinting in the sunshine, giving at once a foreign inpress to the scene, in the mind of the English settler.

Troglodytal in its breeding habits, it seeks some hollow tree or branch in which to rear its young; sometimes its nest is placed between the wood and the dissevered bark of a decaying tree; more frequently at the bottom of some deep hole. The eggs are white, and somewhat oral in shape.

In the gardens sitnated near bush, the Parroqnet becones a great purloiner of fruit. Near Arowhenna and Waimate, we have seen it rising in flocks from the oat-ricks. It is so bold as to be very easily suared with a toluetohe reed, noosed at the tapering point.

It commences breeding in August.

Since the great fall of snow, July, August, 1867 , all bush-biris alont the Malveru Hills appear to have become scarcer ; for quite a year after that great storm, the silence in the buslies seemed quite remarkable, as though entirely deserted by their feathered songsters. This was notably the case in the Rockwood Bush.

\section{No, 5],-NESTOR MERIdionalis, Giml. \\ Kaka. \\ Bush Parrot.}

One of the eommonest of our larger lirds; yet in most of our bushes it is not nearly so numerous as it was a few years since. A troglodyte it may certainly be termed, for in the cloice of a situation for its nesting-place, it secks the shelter of a hollow tree. Sometimes the entrance-hole is a consideral,le distance from the nest, which is merely the decaying woor at the bottom of the hole. It lays four eggs, which, like those of most linds that breed in holes, are white; ovoiconical in form, they measure in length 1 inch 9 lines, ly 1 inch $3 !$ lines. Sometimes, before the young are old enough to vacate the nest, it recomnences laying. It is in considerable request as an article of food ; they are fattest in the great Fagus forests, during the montl of April. It is very easily suared, and readily tamed. The call of one bird in distress will soon canse it to be surrounded by numbers. A very common artifice is to hold a Kaka by the wing, its shrill call soon collects a crowd of its friends on the neightruming 
trees, where they soon fall to the gun of the pothunter. During a few weeks, in July and August, 1856, Kakas were to be seen in extraordinary numbers, they were poor in condition, perhaps tamed by hunger; they alpeared to have lost their wonted vivacity, and numbers were eut over with stock-whips, as they sat perched on the rail fences, about stations on the Malvern Hills. The earliest bird in the bush, its call may be heard long before daylight.

\section{No. 58.--Chrysococcrx lucidus, Gml. \\ Pipiwharaupa. \\ Bronze-winged Cuckoo, Whistler.}

This beantiful little bird, in some districts, is most commonly known by the name of the Whistler. It is so called from its peculiarly clear note, which exictly resembles the sound matle by a man whistling his dog.

It is remarkable for the regularity of its annual visits : in the neighbourhool of Christchurch it is ahmost sure to be heard about the 8th of October. We have a note of its appearing as early as the 27 th of September (1855). The male bird usually selects the topmnost sprays of the tallest trees for his perch, during the time it is giving utterance to its remarkable call; he seldom remains long in one spot, and indulges in a restless jerky motion of his tail. The female may be noticed very silently entering, and peering about scrubby bushes of no great height.

A parasite, like the Cuckoo of our Old Country, it saves itself all the trouble of nest-building by making use of the nests of other birts, and, of course, relieves itself of the care of providing for its young. Our experience points to the little Grey Warbler (Gerygone assimilis) as the most frequent victim of this "gay deceiver." The single exception we have ever observed, was the Petroica macrocephala, another insect-eating bird. We are not quite satistied as to the manner in which the egg is deposited by a bird so disproportionate in size to the nest and its porch-like entrance, as that of the Gerygone. Either this Cuckoo does not destroy the eggs of the Warbler when it makes its deposit in the nest, or the bird lays to the egg of the intruder, as we have taken the nest with three of the IVarbler's eggs, besides the egg of the Chrysococcyx; yet, whenever the young Cuckoo has been found in the nest, it has invariably been the sole tenant, we have not yet been able to observe in what manner the eggs, or young of the rightful owners have been extruded. In selecting the nest of so early a breeder as the Grey Warbler, as a home for its young, it secures certain advantages for the benefit of its offspring which shoukl not be lost sight of. At the periocl of the Cuckoo's arrival the Warbler has most probably reared its first brood, so that even young birls have had time to gain experience in building their habitation and rearing their nestlings; then too, everywhere insect life abounds, so that a proper supply of food, sufficient for comparatively so large a bird, can be obtained by its little foster parents, with less labour and more certainty, than it could have been secured two months earlier, when several birds commence their breeding arrangements. It has been noticed, under Gerygone, why the domed nest is selected, namely, for its warmth. Then, in addition; the Golden-winged Cuckoo, be it remembered, has a most extensive range, even to the tropical islands of New Guinea, Java, and Sumatra-according to Schlegel - (see "Finsch's Notes," p. 118), and it probably chooses a pensile nest, through the same instinct, a regard to the safety of its young, which causes the lately-settled Zosterops to continue, for the present, a pensile nest-builder, though, as we have said elsewhere, we think there are indications of a change in its style of architecture. The selection, male by this Cuckoo, goes to strengthen our idea of the non-indigenous origin of unr pensile nest-builders. The exy, elli, tical in form. prale greenish-rlun in colour, measures 9 lines in 
length, with a breadth of nearly 6 lines. Locality, slopes with manuka serub, in Ohinitahi, Governor's Bay. The Whistler is a great insect eater, and appears especially fond of the well-known laulybirl; we are not withont certain suspicions that it devours or destroys the eggss of other hirds.

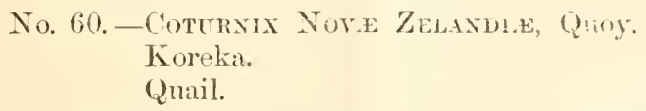

This excellent game bird is almost extinct, but a few rears since it existed in the utmost abundance; bush fires, extending often for many miles, must have been the aetive agent in destroying a bird possessing such linited powers of flight, as onr handsome little Quial.

A very slight nest, composed of a few bents of grass twisted into a depression of the ground, was all the artiticial shelter this bird relied on, for the purpose of incubation. The eggs were very numerons; we have been told that as many as ten or twelve have been found in a nest, oval in shape, colour bufly-white sufinsed with rieh brown splashes, with a remarkably glossy varuish; length 1 inch 3 lines. by 11 lines in diameter. We have not heard its call-mote, or seen a hery of Quail, for years. The sheltered valleys round Lake Coleridge, and abont the heal-waters of the Rakaia, were the list places in which it lingered, to our knowledge. They bred more than once in the season, as we have a note of abundance of young Quail so liate as the 9th and 10 th of April (this was in 185T). We have seen it escape the talons of the Quail-hawk, by dropping perpendienlarly, just when about to be struck, when all hope of escape from its relentless pmrsner was quite abancioned. The flight of the Quail is low, and it used to he said that it would not rise after being flushed the third time: numbers were killed by sheep and cattle-dogs in the early days, when it abounded. In style of flight, our bird must resemble the Quail of Tabarah and Kibroth-hattaavah, that fed the Children of Ismel, in the wilderness:-.. "And there went forth a wind from the Lord and brought quails from the sea, and let them fall by the enmp, as it were a day's journey on this side, ancl as it were a day's joumey on the other side, round about the caml, and as it were two culbits hight upon the face of the earth." Our bird is not migratory as we believe. The young, with the exception, perhaps, of that of Apteryx Ovenii, undergoes less chinge in plumage than that of any other bird ; the young, when it assumes its feather's, exactly resembles the adult female, with the white streak along the shaft of the feathers, which aclds so much to its beauty.

\section{No. 61.-A pteryx aUstralis.} Kiwi.

We have not enjoyed an opportmity of acquiring. from personal observation, any knowlerlge of the breeding-habits of the curious family of Apterygirla: a description of the eggs of the different species may be thought not ont of place in the present paper. We believe this species is peculiar to the Middle Island.

An ego received at the Canterbury Mnseum from Okarito, or its neighbourhood, is believed to be an undonbted speeimen of this species, - it arrived, in a fiesh state, in November. It was white, much blunted at eneh end, and presenting a very smooth surface; this enormous egg gives the following measurements: throngh the axis 5 inches 1 line, with a breadth of 3 inches 4 lines.

Rev. J. G. Wood, in his "Nat. Hist. Birds," writes of the eggs laid by the Kiwi at the Zoological Gardens, Lonton : "These eggs are indeed wonderfinl, for" the birl weighs just a little more than four pounds, and each egg weighs between 
fourteen and fifteen ounces; its lengtl being $4 \frac{3}{4}$ inches, and its width rather more than 2 inches."

The Cinterbury Musenm also contains some fine specimens of the bird, olitained from Westland.

\section{No. 62.-A pteryx Owexil. \\ Kiwi.}

The smallest and most common of the whole family. Specimens of Owen's Apteryx are not very rare in collections, but the celebrity which attaches to this wingless genus is apidly drawing down destruction npon it. No mercy is shown to it, and there is no exaggeration in stating that a regular trade is carried on in specimens of these birds, and the equally unfortunate Kakapo (Strigops habroptilus). Could not our patemal Government interfere in behalf of these interesting aborigines, for we believe there are those who would shoot the Cherubim for specimens, without the slightest remorse. This species is peculiar to the Middle Island.

An egg in the Cinterbnry Museum, from the West Coast, measures 4 inches 6 lines in length, with a brealth of 2 inches 7 lines (other specimens we have neasured are of rather larger dimensions); colour, white, with a very smooth surface, blunt at each end.

The yomg of the Kiwi, withont exhibiting any sign of an immature state of plumage, is disclosed, as it were, from the shell, arrayed in the hairlike integument of an adnlt bird. In this species the mottled-grey feathers of old and young appear to be of same shade of colour.

\section{No. 63.-Aptekyx Mantellit. Kiwi.}

This is usually known as the Kiwi of the North Island, and it is believed that it has become comparatively rare during the last few years.

An egg, in om own collection, from Whangaroa, measures not less than 5 inches 4 lines in length, with a brealth of 3 inches 3 lines. This specimen is white, of smooth surface, rather more pointed at one end than is usually the case with the eggs of this family.

\section{No. 65.-Charadries Bicinctus. \\ Banded Dotterel.}

The fimily of the Charadrize have always been distinguished for their wariness, and the artful devices employed to allne strangers from their nest. Teliodorus gives snch a singular reason for its shyness, that we cannot resist quoting it: "The bird Charadrius cures those who are afflicted with the jamblice. If it perceives, at a distance, any one coming towards it, who labours under this distemper, it immediately runs away, and shnts its eyes; not out of an envions refusal of its assistance, as some suppose, but becanse it knows by instinct, that, on the view of the afflicted person, the disorder will pass from him to itself, and therefore it is solicitons to avoid encountering his eyes." Our banded Dotterel is worthy of belonging to the family of the Charadrie, for it is one of the most restless and wariest of birds, during the breeding season. On the approach of an intruder, it flies round and round, nttering its note of warning, then alighting on some rising ground, it steadily keeps watch. During the time it remains on the look ont, it induges in a peculiar habit of jerking its head backwards and forwards, uttering its monotonous twit, twit, at intervals.

It commences breeding early in the spring; its simple nesting-place may be found on "the plains," or in river beds. It lays three oval-shaped eggs, 
greenish-lrown, much sprinkled with dark-brown markings; they measure 1 inch 4 lines in length, with a breadth of 1 inch.

The young are exceerlingly active, the little brown puffs of down may be olserved runuing with great swiftness on being alarmed. In the antumn the Dutterel assembles in flocks of consirlerable numbers.

Notes.-August 2, 1856, saw a nest and two eggs, Rakaia river. September 1, 18.56, saw nest and three egros, Rakaia river. October 14, 1857, young birds quite strong.

\section{No. A. 65.-Charadrius obscurus, Gml. Tituriwhatı-pukunui. Red-breasted Plover.}

In Dr. Finsch's list, in Vol. i., "Transactions New Zealand Tnstitute," this Plover is named Hamatopus obscurus.

This handsome bird is to he met with on liill and plain, yet nowhere in very considerable numbers. In the breeding season we have noticed it at such a considerable altitude as the summit of Dog Range, in the Ashburton district. The nest is difficult to find, it is so slight an affuir that it easily escapes observation, merely a few stems of grass twisted into a slight hollow in the ground, so loosely put together that it is not easy to pick it up and yet preserve its form. The eggs, three in number, just fill the nest; they are of a clelicate soft-brown, suffused with dark-hrown, almost black, marks, somewhat oval in shape, in length 1 inch 9 lines, with a breadth of 1 inch 3 lines. The young run with speed almost as soon as hatched, and conceal themselves with much skill. Young birds have not the rufous tinge on the breast and upper part of the abdomen. We liave olserved eggs and young in the months of October and November.

Note.-Oet. 22, 1867 -Nest with three eggs; - Saw young Plovers.

The warning-note of this bird sounds like elick, click, slowly repeaterl.

An excellent figure of it, rather warmly colonred, is to be found in Ross's "Voyage of the Erebus and Terror," Vol. i., plate 9, Birds.

\section{No. B. 6.5.-Axarhymelues froxtalis, Quoy. and Gaim. Scissol-bill, \\ Crook-billed Plover,}

Appears in Dr. Finsch's list, "Transactions New Zealand Institnte," Vol. i., as Hamatopus fromtalis.

The Crook-billed Plover, at the breeding season, is less wary than any of its congeners, and its nesting-place would be discovered with very little difficulty, were it not for the wonderful instinct it exhibits in selecting the ground for depositing its egres. They are simply laid, without any preparation, anongst the pebbles of some river-bed usually, and never far from water, and so well does their grey tint harmonize with the general colour of the shingle around them, that their detection would be almost hopeless if this bird was less conficlent.

Its oval-shaped egos are three in number, grey stone-colomr, with the whole surface minutely dotted over with black specks; they measure 1 inch $4 \frac{1}{2}$ lines in length, with a wilth of 1 inch $\frac{1}{2}$ line. On approaching the eggs or young, the old birl trots slowly away, assuming a hrouter and somewhat flatter appearance, ly slightly extending the wings, making at the same time a low purring sound.

Breeding season extends from September to December.

The young birds are covered with grey down, and appear to have legs long, ont of all proportion to the size of the borly; at this early stago, the peculiar cleflection of the bill, although slight, is pereeptible; it is always 
turned to the right, or off sicle. Birds of the year, we believe. lo not assume the frontlet which distinguishes the old birds, and which is bandest in the male. No satisfactory reason has been given for the peculiar form of the bill of this birl, which exceeds in length that of $C$. bicinetus.

Tores.-Fept. 14, 1856-Saw three eggs on a patch of small shingle.

Uct. 28, 1857-Young birds on the Rakaia river-berl.

Oct. 30, 1867-Two eggs on the bare shingle, Rakilia river.

Nov. 2, 1867-Three eggs chipped, on shingle, Ashburton river.

No. 71.-H.Henatopus Longirostris, Vieil.

Torea.

Oyster-catcher; Red-bill.

The Orster-catcher is one of the wariest and most restless of our birds, ever reaty with its clamorous almim-note, to wake np each echo, and disturb every bird within the sound of its shrill cry; but in the breeding-season it exhibits an intensity of slyness, that is almost smpernaturil. Usually it breeds in our river-beds, on the sandy spits, without other shelter than what may be afforded by some drift flax, grass, or stick, near which it makes, or discorers, a slight depression, in which to deposit its eggs, which are somewhat oval in shape, 2 inches 3 lines in length, with a liameter of 1 inch $7 \frac{1}{2}$ lines; pale or yellowish-brown; these are not to be distinguished from those of the European biril, much covered with irregular matks and spots of rich brown. Usually three eggs are luid, but we lave foum it incubating a single egg: the young are grer, with a dark longitudinal stipe on each side, above the wing. They are very active, and are early led by the old birds to the margin of the waterholos or pools. On being alarmed, the old bird sidles off the nest quietly, takes alvantage of any broken ground that apparently conceals its movenents from observation, ani makes a long detonr; a close scrutiny will very frequently enable the observer to detect the head of the bird carefinly peering ont behind some vantage-ground, watching all his proceedings.

A very common frequenter of the coast, as its familiar name imports; in the winter time it assembles in large flocks on the mud flats disclosed by the ebling tile; thongh a shore-bird, it is found breeding in solitary couples, often fur inland, certainly sixty or seventy miles from the sea, for instance, up the Wilberforce river, nearly as far back as the neighbourhoor of Browning's Pass. A par will boldly attack the Harrier, male and female striking at the Hawk in turn, and driving it to a safe distance from their young. Hrmatopus, that is, literally, the blood-red foot, one of the birds mentioned by Pliny, appears to be universally met with.

\section{No. 75.-Botaurus poicilopterus, Wagl. Mitukuhurepo. \\ Bittern.}

Not so frequently met with as before such an extensive breadth of swampland had been drained and cultivated. It was once very common about Christchurch, "the City of the Plains," it still hamnts the banks of the Avon, and breeds in the neighbouring swamps. The breeding season of the Bittern must extend over a consilerable preriod, as we have found the ergss, quite fresh, in the middle of Jannary (15th). A nest near Clearwater, or Lake Tripp, in the Ashburton country, was built of raupo, (Typha anegustifolice), surrounded by water abont ankle deep; the top of the nest was very flat, and stood about six inches above the surface of the water. (See Plate 4, Fig. 7.) We have not seen more than four eggs to a nest, they are oval in form, varying slightly in colour, from buffy-lown to pale olive-green. Through the axis they measure 2 inches $1 \frac{1}{2}$ lines, with a diameter of 1 inch 6 lines. 


\section{No. 78.-Himantopus Noye Zelandie, Gould. \\ Poika. \\ Pied Stilt.}

Usually commences breeding in October, according to our experience, Unlike the black variety, we have always found this bird prefer's swampy ground, such as fringes the shores of shillow lagoons, as a nesting-place, ete. Here it may be observed busily wading in the shallow water. In its habits of nidification, it is as inartificial as its congener. Eggs, four in number, yellowish-brown in colour, about the same size as those of the Black Stilt, are profusely marked with very dark brown; we have thought the eggrs rather warmer in colour than those of the black variety. The monotonous call of pink, pink, has, in some places, fixed on it the trivial name of Pink.

No. B. 78.—Hunavtopus melas, Homb. et Jacq., "Anm. des Sci. Nat., 1841." Black Stilt.

Breeds early in the season, seeking the sandy river-beds for that purpose. The labour of nidification is very tritting, sometimes a nest of grass, etc., is roughly constructed, now and then this apology for a nest may be discovered on a log of drift-wood; much more frequently, howerer, a slight depression in the sandy spit, answers all the requirements of this Stilt, as a nesting-place ; it is never very far from water.

It lays from three to four eggs, rather oval in shape, jellowish-brown in colour, very much spotted and blotched over with very dark-brown, approaching to black, measuring 1 inch 10 lines in length, by 1 inch 3 lines in breadth. The young can run almost as soon as they are hatched; when disturbed, they conceal themselves behind stones, or some other shelter, in the most artful manner; they are covered with dark-brown down, bills and legs are then very dark, almost black. The parent birds exhibit the ntmost assiduity in attempting to lead intruders from their eggs or young, and their numerous cumning derices are carried on with surprising cleverness and persererance.

We have been told that there is not a Black Stilt, that the Black Stilt, so called, is, in reality, but the pied species in an immature state of plumage. To this we cannot for a moment subscribe, we have never once found the two species breeding together or using the same, or eren similar situations, for their nesting-place.

Neither Mr. Buller nor Dr. Finsch, we remark, admit this bird in their lists, but, with the utmost deference to those authorities, we cannot consent to give up such an old acquaintance as the Black Stilt. Our opinion on this subject, is shared in by many others, living "up country," who have had good ojportunities, for several yeurs, of observing the hreeding habits, and the young birds of both species of Stilts.

Notes.-Sept. 13-Nest with three eggs, on a spit on Rakaia river-bed. Dec. 11-Nest with two eggs, on a drift-log in the Rakaiat river-bed.

No. 87.-Ocydromus australis, Sparm.

Weka.

Wool-hen.

This bird is so mischievous to the fruit gatrden and ponltry-yard of the up-country settler, that unrelenting war is usuilly waged against it. Small fruit, low-growing apples, eggs, and young chickens, form some of the items of its farourite plunder; nor is its thieving propensities confined to articles of food, spoons, pipes, pannikins, and a long list of miscellineons articles, we have known this curious collector to carry off. On one occasion, in Alford Forest, 
a watch was stolen, and accidentally recovered, a few days after, at some little distance from the hut; for the Wekit, mlike the Jackliaw at home, does not appear to care for a secret hiding-place in which to conceal its pilferings.

We bave seen it kill a well-grown Spanish chicken, six weeks old, with one blow of its powerful bill. Some time since, a Weka appeared in our garlen, much to our gratification, for, in the neighbourhood, the bird was of very rare occurrence; all went well till the first brood of choice Dorking chickens was discovered, and then, well, the Weka had to die.

At night, and before rain, the lourl screaming of this bird is most frequently heard. The nest is found in a variety of situations, such as in a tuft of Celmisia, grass-tussock, or sometimes in a thicket of young plants, on the outskirts of the bush; we have observed it uncler the shelter of a rock, without any attempt at concealment, which the tussocks growing close by would have afforded. Grass is usually the staple material of its home, which is large, and basin-shaped within. The eggs, from five to seven in number, are white, with reddish marks generally distributed over the surface ; but in many specimens the colouring is most abundant at the larger end. The young, covered with very dirk down, may be observed, like chickens, following the old bird, who collects them around with the eall of toom, toom, repeated quickly, and much lower in tone than the booming note to which the Weka sometimes gives ntterance, and which is probably the call of the male. As the young grow up, the dark-brown of its early days gives place to a more mottled plumage when abont one-third grown; althongh the legs become lighter in colour, the beak still retains its dark appearance. There is much difference in the size of Wekas, some of the hill-birds are very large, and we expect that before very long they will be classed as a separate species.

A very light-colonred specimen was observed near Mount Hutt, last year. Numbers of these birds are killed for their oil, which is much esteemed by bush-men for a variety of purposes ; properly dressed, they are excellent as an article of food, due care being taken as to where they are obtained, as they are very foul feeders.

\section{No. 9l.-Porphyrio melanotus, Temm. \\ Pukeko. \\ Swamp-hen.}

This beautiful rail delights in swamps, where its nest is also to be found, built of grass; the top is sometimes more than a foot above the ground, and not unfrequently it naxy be observel sumpounded by water. The number of eggs to a nest varies consiclerably, as we have found from two to seven, five may be considered the usual complement, in shape ovoiconical, greyish-brown, with dots and blotches of redlish-brown, measuring throngh the axis 2 inches 2 lines, with a dimeter of 1 inch 6 lines. These dimensions appear very small for so large a birl, more especially when compared with those of the egg of Apteryx Muntelli. The young rum about as soon as they are hatched, and on being disturbed conceal themselves with great art. They are thickly clothed with black velvety down, interspersed with fine hair-like points of silver-grey; legs dnllish-red, beak has a yellowish ivory look, which contrasts pleasingly with the rest of the borly. The Pukeko is esteemed excellent eating.

\section{No. 92.-Casarca variegata, Gml. \\ Putangitangi. \\ Paradise Duck.}

This well-known bird often chooses the shelter of a huge tussock, beneath which to make its nest; sometimes a hole in a rock is chosen in preference. 


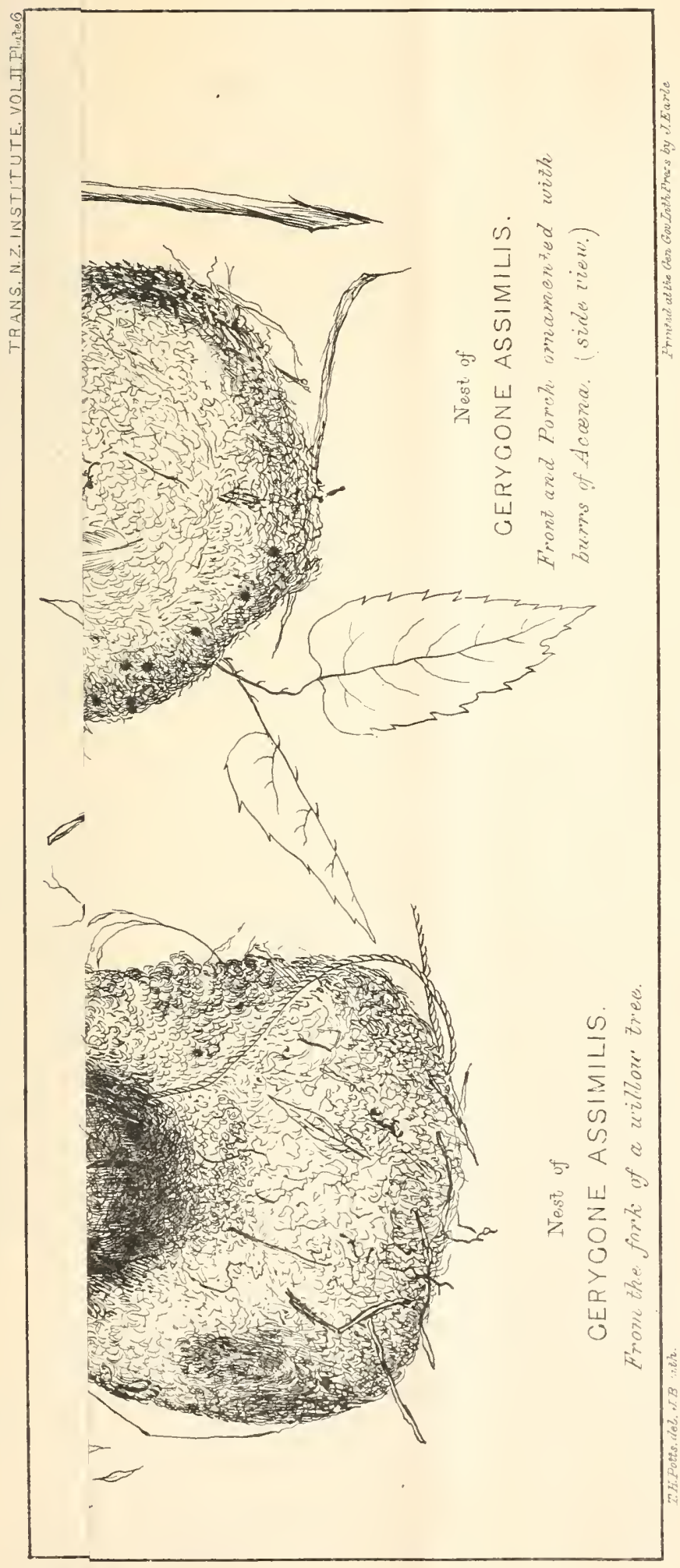




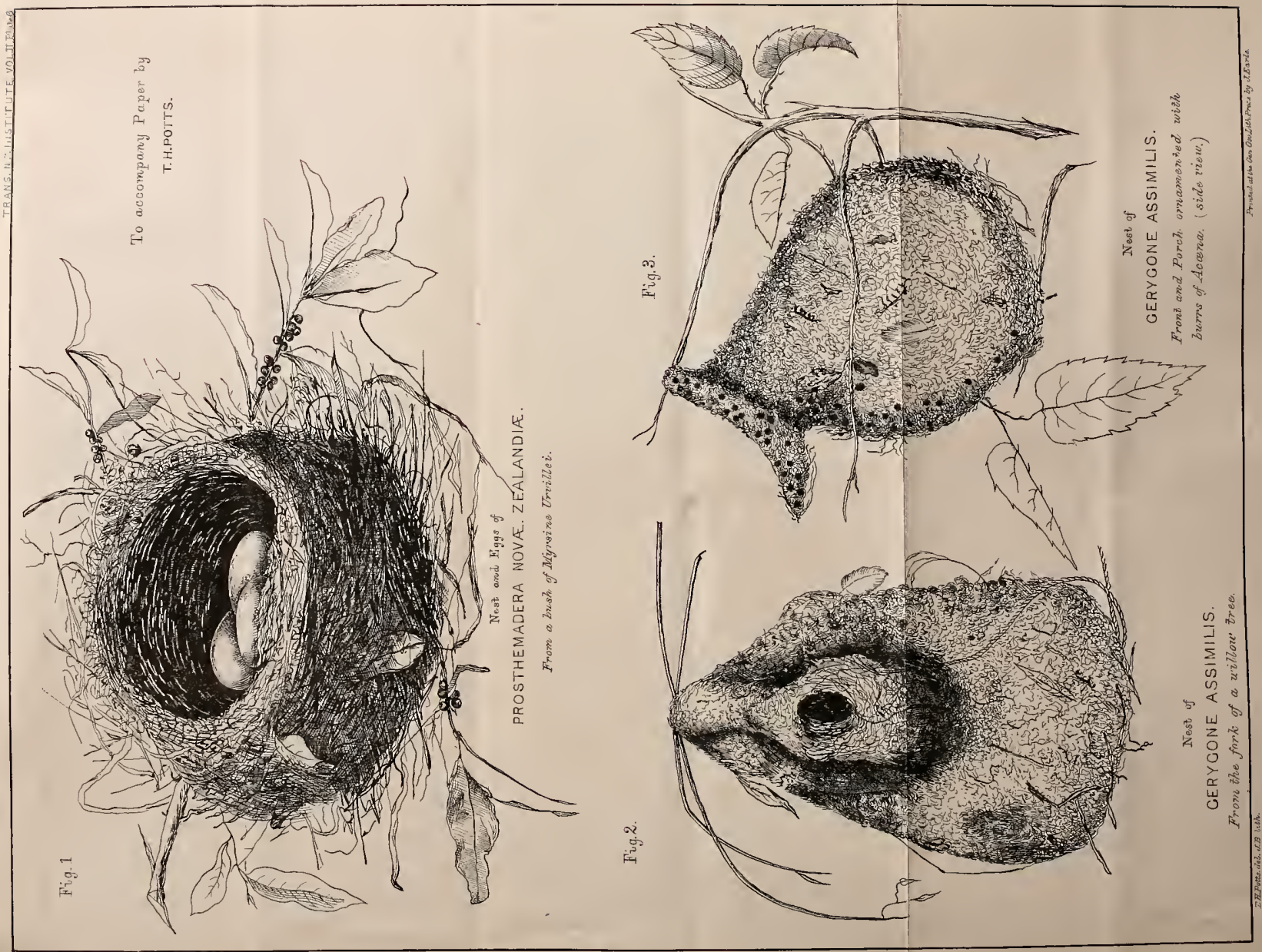


We know a large rock, on the bank of the Rakaia, where a pair of these birds breed every year.

The nest is warmly lined with down; nine egors are sometimes found in a nest, but not often have we noti sed so large a number; they are large, creamywhite, ovoiconical, vary somewhat in size, even in the same nest; length 2 inches 9 lines, with a diameter of 1 inch 10 lines. The Paradise Duck leads its brool to water very soon after hatrhing. The parent birds may be noticed surrounded by their tiny young ones, spending nearly the whole dity upon the water, even when the usually smooth surfuce of the lake has been lished into foam-crested waves by a furious Nor'-wester. They enter the lake after the sun is well up, and remain till late in the aftermoon ; this is daily repeated, the young birds gradually venturing firther fiom the old ones, and may be observed clarting abont with the greatest activity.

This bird employs the wiliest stratagems to lead the wayfurer from its nest or young.

Notes.-October 24, 1855, noticed nest with eight eggs, Malvern Hills.

November 1, 1867, sitw nest with five eggs, another with six eggs, on the Potts river.

December 2, 1867, Duck sitting on five eggss, Rangitata river.

The eongress of the sexes takes place in water, after the manner of the common Goose. Whien young, the flesh of the Paradise Drek is very good eating, but in old birds there is a degree of toughness, that only the sharpest appetite can overeome.

The young are easily tamed, and feed amieably with other poultry ; but unless contined when spring sets in, they are almost certain to ramble away and be lost.

\section{No. 93.-Anas superciliosa, Gml. Parera. \\ Grey Duck.}

One of the eommonest game-birds left to us by the eager sportsman. We have found the nest of the Grey Duck in so many sitnations, diflering so entirely in eharacter, that it wonld be difficult to pronounce any one position as the favourite site for its breeling-place. Sometimes close by the edge of a bush creek, amongst damp shady ferns; ont on the plain, sheltered by a tussoek, quite away from water; often on a hill side. Yet, whether on the level plain or in a swamp, its cup-shaped nest is most profusely lined with down, and diffuses a strong musky odlour. The eggs, usually nine in number, are ereamy-white, occasionally varying a little in size and shape, some are ovoieonical, others broadly oval; 2 inches 6 lines through the axis, with a diameter of 1 inch $8 \frac{1}{2}$ lines, is the measurement of a large specimen; whilst we possess speeimens that measure but 2 inches 3 lines in length, with a diameter of 1 ineh 7 lines. On referring to many notes on the numbers of eggs laid by the Grey Duck, an entry appears of ten eggs in a nest, found December 10th, near a lagoon by the Rangitata, the largest number of which we have a memorandum. We have seen the young quite tame, and associating with the common domestic Drek.

\section{No. 94.-Anas chlorotis, Gray. Puteke. \\ Teal.}

Very mueh scareer of late years than we can remember it. A few years ago we used to hear tales of almost incredible balgs of this excellent gamebirl; a few more years of ineousiderate slaughter, will milke the Teal a rarity. 
The nest is made of grass, thickly lined with down, sometimes close to the cdge of a swamly creek, or beneath the sheltering leaves of a large "Maori-head" (Carex viryate).

The egrs are large for the size of the bird, cream colour, not mnlike those of the Mountain Duck, in tint, but perlaps slightly darker; length 2 inches 5 lines, dianeter 1 inch 10 lines, WVe have not found more thin eight eggs to a nest. On a pond at Rockwood, in the Malvern Hills, three Teal fraternised with some tame Paradise Dncks, and came regularly, to be fed, every day, with pieces of bread.

\section{No, 96.-Fuligula Nove Zelandie, Gml. Papango. \\ Black Wiilgeon.}

In the hill-country, a few years since, this was sufficiently common; a small tarn, near Lake Coleridge, yet retains the name of Widgeon Lake, from the numbers which formerly frequented it. Near one small pool in the Ashburton country, where it lred in considerable numbers, neither birds nor nests are now to be met with.

A gregarious bird, it delights to assemble in large flocks, and may be seen on some of the more secluded lakes, swimming about, and disporting with numbers of other water-fowl, very frequently diving. Sometimes it breeds in the shelter of a huge "Maori-head." We have found it well concealed by a large snow-grass tussock, within a few feet of water, where there was a rent or crick in the giound. Nest of grass, thickly lined with down, contained five eggs of a deep cream-colour, oroiconical in form, measuring 2 inches 8 lines, with a diameter of 1 inch nearly 9 lines.

\section{No. 98.-Hrmenolamus malacorhynchus, Gml. Whio. \\ Blue Duck, Mountain Duck.}

The only way of seeing this singular bird to advantage, is by paying a visit to the momntainous districts. On a mountain torrent, where the foaming water dashes from rock to rock in comntless eddies, the Mountain Duck lives at ease, making its way up or down stream. Sometimes it may be observed basking in the sminshine, near a shallow pool of the rapid streamlet. Sometimes it is a burrower, and its nest may be found in a hole in a bank; we have found it concealed from view by overhanging sprays of those various alpine Veronicas, which sometimes make the monntain creeks in the backcountry perfect gems of beanty. The nest, like that of other ducks, thickly lined with down, we have found to contain five eggs, of a deep-cream colour, elliptical in form, measuring 2 inches $8 \frac{1}{2}$ lines in length, with a diameter of 1 inch 9 lines.

One of our early breeders; we have known the young brood to be swimming about by the end of September. We have seen nests of eggs in October and November. A much freqnented breeding-place is above the gorge of the Potts river,- - a tributary of the Rangitata.

\section{No. 99.-Podiceps rufipectus, Gray. \\ Totokipio. \\ Dab-chick, Little Grebe.}

This bird is far from uncommon, and is to be met with on lakes, lagoons, and deep creeks that run still and swift, unlike the noisy torrents in which the Mountain Duck delights.

The nest is rather a large and somewhat clumsy structure, formed of the roots and leaves of various aquatic plants. We have foum it built against 
the stem of the Carre virytu, heneath the droping leares of which it was purfectly concealed from casual observation. Situated just within the swampy side of a small lake, it was raised a few inches, only, above the water-level. We have invariably fom two eggs to a nest; they are greenish-white, frequently with wart-like protuberances, and more or less weed-stained.

Egrgs fion the same nest occasionally differ a little in size, as may be observed from the following measurements: length 1 incli 9 lines, hy a liameter of 1 inch; whilst another egs, from the same nest, measured in length 1 inch $6 \frac{1}{2}$ lines, with the same cliameter as in the longer specimen. The lobed foot of the Grebe is a remarkable peculiarity, assisting it to swim aml live with great rapidity; in its habits it a]pears mnch more restless and filgetty tham the large Crested Grebe. The young is greyish-hrown on the back, warn-rufous on the neck and breast, lighter on the abdomen ; the hear is beatifully mottlerl with black, and rich redilish-brown alternately. When alarmed on the water the parent birds have a knack of tucking the young muler the wing, so that its head is alone risible; they dive and swim, thus encumbered, with the greatest ease.

\section{No. 100.-Podrceps Hectori, Buller. Crested Girele.}

One of the most ornamental of the water-fowl, that add so much to the interest of the lake scenery of om Southem $\mathrm{Al}_{1}$ s. In $\mathrm{A}_{\mathrm{r}}$ ril, 18.56, we first mate its acquaintance, on a sinall lake, now called Lake Selfe. It appears to move about in prirs, as a single conple is nstially found (or rather was to be found) associating with nearly every gromp of Ducks that dotted the little secluderl balys of the lakes.

The Grebe swims low in the water, with a certain air of demure gravity, which affords a maiked contrast to the ranjid movements of most of the other natatorial birls, with which it so frequently associates.

Wre have fouml the nest in November and December. The structure is lizrge, and rery sulinly built of pieces of lecilyed Carea viryatu, raised abont a foot above the level of the witer ; its sloping sides give a realy means of reaching the basin-like dryession on the top, in which the eggs are rejosited. (See Plate 4, Fig. .5.) In several instunces we have obserred that the nest hal been constructed on the top of an old stump of C'arex cirgutre, sitnated in a shallow part of a lake, distant from twenty to one lumclied rards from the shore. Last Spring. in the little boat-harbour on Lake C'oleridge, helonging to Mr. Oaktien, thitre lisplened to have been thrown a quantity of eut flax, which the bight of a chain prevented from chifting ont to the lake; a pair of Crested Grehes built on this floating mass, and succeeded in rearing their young; it shond be adiled, this harlour is not much used, and the proprintor is a carefnl protector of our native binls. We have known thee instances, in which the nissts lave been suimerged by the rising waters of the lake, an indication that such mishilys must fiequently ocenr, which may perhaps in some measure accont for the comparative rareness of this Grebe.

The eggs, three in number; are at first greenish-white, but very quickly become stained over, entirely, with yellowish-brown, from the water and weedy slime adhering to this hirl's flat lohed foot. Eggs elliptical in form, measming through the axis 2 inches 4 lines. with a breadth of 1 inch and nearly $i$ lines. We believe that an interval of two, perhatps thee, days occurs between the laying of each egg. The young bird is pale-hrown with dak brown marks. During incubation the Crmbe nuintains an nuight posture, with its long graceful neck hell crect, so motionless its attitule, that at a distance it rather resembles a stick thim anything aubed with life. Watchiful and shy, it noiselessly dives, inmediately it discorers itself observed. The 
power of diving, and the faculty of remaining under water for a considerable time, is too remarkable a characteristic of this bird to be passed over without notice.

\section{No. 104.-Spieniscus minor, Forst. \\ Kor'or:a. \\ Small Pengnin.}

One of our commonest sea-fowl; and certainly a frequent burrower in its mode of nidification.

We have found the Penguin breeding every year, in the inner chamber of a deep cave, perfectly diuk; a loollow, scraped out of the sandy lottom of the cavern, half filled with fish bones, formed the nesting-place, in which the eggs were deposited. We have always fouml two eggs, as the complement of the Little Penguin.

The eggs are white and very smooth, but soon become stained; they are broally oval, and measure, throngh the axis, 2 inches 2 lines, with a diameter of 1 inch 9 lines. The old birls defend their nests with great spirit, using beak and claws most vigorously, making at the same time a noise not unlike the mewing of a cat.

We have observed these birds breeding during the months of November, December, and Jamiary. Th'y breed in great numbers amongst crevices of rocks; in sand-banks, their tumnels are bored with great neatness, with a run frequently extending a considerable distance. The entrance generally exhibits a perfectly round hole, ahout three or four inches in diameter, and from whence is diffused a most powerful odour. The young, we have found in the nest when nearly full-grown ; their slatey-bluish phumage is brighter than that of the parent birds. We have an egg, very much encrusted, showing a departure from their usual appearance, which is usually as white and smooth as that of the domestic fowl. In retreating to the sea, its action is peculiar, walking it can scarce be called, it appears to throw the whole borly forward, and shuflles along with an undulating motion, which gives the Penguin more the appearance of a large grey rat than that of a bird.

\section{No. 126.-Larus doninicanus, Licht. Kororo. \\ Grey Gull, Black-backed Gull, Large Gull.}

Onr larger Gull breeds on the sea-shore, upon the sandy spits in the riverbeds. The rough-looking nest is large, nsually made of grass, sometimes of small tussocks pulled up by the roots. We have noticed these birds visiting the breeding-ground early in Angust, but have not seen the eggs till some weeks later, apparently these must have been visits of inspection, when they busied themselves about the nests in rather a clamorous manner for several days in succession. The eggs, two or three to a nest, are ovoiconical, measuring 2 inches 10 lines in length, by 1 inch 10 lines in width. The colour varies from shades of light-grey to brown, covered, more or less, with grey and brown marks and blotches. The young are well covered with grey down at first, they assume, gradually, a mottled-brown plumage, the bill still clark, presenting a marked contrast to alult birds. The parent birds defend their nest with great spirit, a pair will drive away, and give chase to, a Harrier. Their olfactory organ must be most acute, as they find out the carcase of a dead sheep or bullock with great readiness.

We have often been amused ly watching their grotesque action in following a retreating wave, where the sea has rolled in heavily on the inclined sandy beach. A number of these Gulls wait till the wave has just expended 
its force and follow the retreating waters rapidly, by a series of holping jumps, feeding the while, and sometimes only just aroidling the next incoming wave, by taking wing for a few yiurds with apparent relnetinee.

\section{No. 127.- - I arus scopulinus, Forst. Tara-punga. Little Guill.}

During the breeding season, ou very pretty Little Gull frequents the river-beds, and shores of lakes, in very large numbers. It leposits its egrgs with scarcely any of the preparation that distingnishes the larger specits of Gull. The eggs are usually found on the bare ground ; at most a few bents of grass, amongst the stones, sufficing for a nest. The eggs, often broally oval, sometimes ovoiconical, are of different shades of greyish-brown, plentifully besprinkled with darker marks and blotches of grey and brown. Length, 2 inches 1 line, by a diameter of 1 inch 6 lines.

\section{No. 129.-...STerna caspia, Pall. Fish-hawk.}

This fine Tern is content with merely a hollow seraperl in the sand, just large enough to contain the eggs; the breeding season extending from November to Jannary; onr earliest note of having seen the egg, is daterl November 14 th.

The eggs, usually two or three in number, ovoiconical in form, measne 2 inehes 7 lines in length, with a diameter of 1 inch 9 lines; we have a specimen from Lake Ellesmere, much smaller than is shown by this measurement; the eggs are of varying shades of pale greyish-brown, riehly spotted with dark-grey and brown, distributed all over the surfuce; in some specimens these markings are most numerous at the larger end. When these hiris are distmberl at breeding-time, they ascend to a great height, and hover around the intruder, nttering lond screams. We lave fonnd the young as large as the adult Lams scopulinus, before they were able to fly. Have found this bird incubating a single egg.

\section{No. 130._-Sterna Longtpenvis, Nordm. Whale-bircl.}

The black-billed, swallow-tailed Whale-lind seems constantly to frequent om coasts and harbonrs, the liveliness of its movements on the wing, especially the rapidity with which it drops from a great height to secure its finny prey, frequently renders it an object of remark to the lwellers on the sea-shore, it deposits its egg on the bare rock, withont the slightest protection, at a distance varying from about five to six feet and npwarls from the level of high tide; the egg must often lie within reach of heavy showers of spray. Ovoiconical in form, generally, but sometimes rather oral, the egg measures 1 inch 10 lines in length, with a diameter of 1 inel 4 lines. Colour varies from shiules of pale-grey, sea-green, stone-colour, or light-brown, lightly freckled with brown, or profusely blotehed with slatey-grey, and chesnnt-brown, to almost black. The young covered with mottled-ygey down, varying in shale to almost hrown, are quite helpless for two or three weeks after hatching, and appear quite unable to attempt securing safety by swimming, like young Gulls, when alarmed; they retain the grey feathers on the head even when well-grown. Great quantities of small fish may usually be noticed smromuling the youmg birds. We believe this bird larys but one egg, but are aware that other's entertain a different opinion. On a rocky point, in Port Cooper, which is 
Washer with almmlant showers of spray muer a strong Ni.k. breeze, we olsopved abont 200 birds breeding; excepts in three cases only, the eggs were solitary.

Note.-Dee. 14-Found two exges lying together, difforing in size and colonr so much, that there is not much donist they were the produce of difierent lirils.

\section{No. 131.-Strrea antarctica, Forst. Conmon Tern.}

In this paper on our Birls, the nomenclature followed is that which is given in Dr. Otto Finsch's Notes, "Trans. New Zealand Institute," Vol. i., p. 12.-5, but in the case of this bird we prefer allheriug to the name assigned to it by Forster. In a note in the volume referred to, page 121, S. rutarctica, Forst., is asserted to be the same species as $S:$ mimuta, Linn. Mr. Buller, in his "Notes on Herr Finsch's Roview," tacitly arlmits this by his silence; we think this must be an error. Yarrell, in his "History of British Birls," Vol. iii., p. 525, writes of S. minuta, "their eggs are of a stone-colour, spotted and speckled with ash-grey and dark chesmut-brown, the length 1 inch 4 lines, by 11 lines in breathe." This measurement is exactly the size of the eggs of the next species, which we have numbered A. 131, whereas the eggs of the yellow-billed $S$. anturetica measure in length 1 inch 6 lines, by a brearth of 1 inch $1 \frac{1}{2}$ lines, and present a very striking contrast in colom ; they differ also in shipe. On referring to our collections of British and New Zealand egrss, and comparing the eggs of these species of Terns, any hesitation we may have entertained about the correctness of allhering to Forster, instead of the more modern anthorities, is removed. The Common Tern, very often termed the Whale-bird, seems even more gregarious then its congener s. lomgipennis, that is, taking into consideration its haluits throughont the year. It may be olserved hovering over the newly-plonghed fields in great numbers, in search of larve of virious insects ; the small lizard seems a farourite morsel, and may frequently he notices slangling from the beak of this Tern.

We have remarked, several times, a curious habit of this bird, which presents a singular appearance to the gaze of the traveller: a large flock will rest motionless on the ground, with their delicate bluish-yrey wings extended vertically, and will maintain this singular posture for some time. It deposits its exrs, two in mumher, on the bare gromul, withont any attempt at niclification; ovoiconical in form, they measure in length 1 inch 6 lines, with a breadth of 1 inch $1 \frac{1}{2}$ lines. In colour. very considerable varicty is exhibited, dull grey, greenish-white, pale-green, pale-hrown, with small brown morkings distributed over the surface generally. This Tern is remarkibly elamorous at the breeding senson ; and sliould a traveller anproach their wromd, the intruder is instantly assailed by them with swift dirtings, accompranied hy noisy, harsh, grating sereams. The young birds remain about the breeding-giound for some weeks, till they can fly well.

\section{No. A. 131.- Sterna_-(?) New Sp.}

A very small Tern visits the Rakaia river-bet during the breeding season, not far below the gorge of that great river. There does not appear to exist any description of it, either in Mr. Buller's Essay, Dr. Finsch's Notes, or in Mr. Buller's Paper of August 25, 1868. It lays its eggs, two in number, on the bare ground, they are stone-colom, blotched over with grey markings, and measure through the axis 1 inch 4 lines, with a dianeter of 11 lines. It is not at all a common birl in that locality, and was not observed there last year. In the Museum at Christchurch. are two specimens of a small Tern, obtained in the province; in all probability, the eggs noticed above, beloug to indi- 
viduals of this species. They are labelled, Stermuld mercis, and measure, total length 10 inches $7 \frac{1}{2}$ lines, length of wing 9 inches $1 \frac{1}{2}$ lines, bill from galpe 1 inch 9 lines, tarsus 7 ! lines ; colour, above, silver or French-grey, forehead white, back of head and nape of neck black, black streak round the eye, bill and feet yellow : the eggs above noticed were discovered in November.

Since the above was written, through the zeal of a friend resiling near the Rakaia, we have received two eggs of this interesting bird; they were fouml in November, hard set. On compraring them with the egg of 'S. mimeta, of Emrope, in our own collection, we find them of rather a broader oval in shape, of the same length, with a breadth exceeding that of the Emropean sprecies by $1 \frac{1}{2}$ lines; but so close is the general resemblance between them, that they might be easily supposed the produce of individuals of the same species. The egg of the Lesser Tern, $S$. minutu, is less eccentric in its colom and marks than those of many other species of the genus.

\section{No. 139.-Graculus Brevirostris, Gould. Black River-shag.}

Breeds on the shores of the lakes in the interior, where these birds congregate in considerable numbers, probably depending on the fresh water Unio, for some portion of their food supply. Like the Rook, and the Heron, of Europe, it builds in company, within the space of a few square yards mamy nests may be connted; the farvourite breeding-place appears to be scrub, on some of the steep and lofty banks of the lake shore. The nest is large, chiefly constructed with sticks procured from the dead scrub, amongst which may be found the dead flower-stalks of Acipleylle squarrosa, grass forming the lining material. The eggs, four in number, are greenish-white, with the chalky encrustations characteristic of the Pelicanidie, ellip,tically shaped, they vary considerably in size, especially in the measurement through the axis, as from 2 inches 6 lines, to 2 inches $2 \frac{1}{2}$ lines, with a brealth of 1 inch 6 lines. When freshly procured from the nest they give out that peculiar odom which distinguishes those of the Procellaridie, in common with the eggs of the Pelicanidæe, truly "a most ancient and tish-like smell."

\section{No. 142.-Dysporus serrator, Binks. Gannet.}

An egg of this bird, in the Colonial Museum, Wellington, gives the following measurements, which correspond very nearly with the size of the English species: length through the axis 3 inches $1 \frac{1}{2}$ lines, with a breadth of 1 inch 10 lines. White in colour, with the rough chalky surface which distinguishes the eggss of the Pelicanidie. 

• 






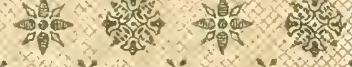

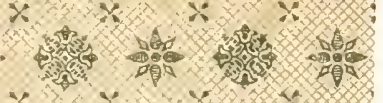

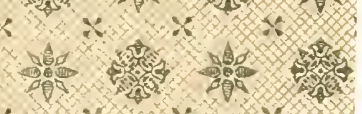

to

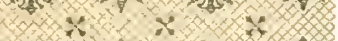

40. +

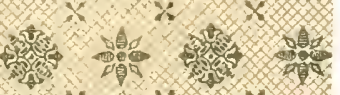

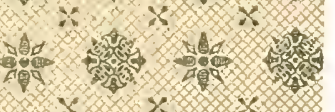

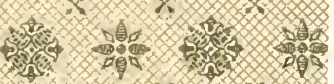

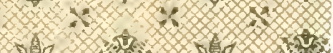

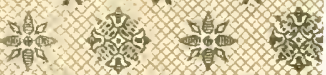

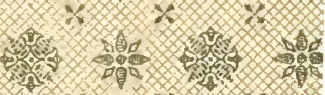

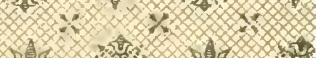

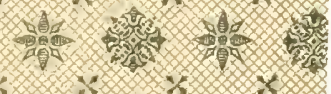

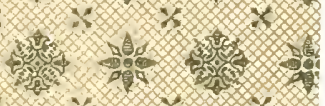

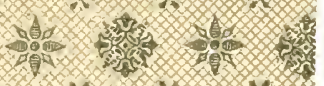

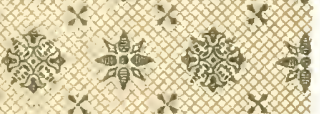

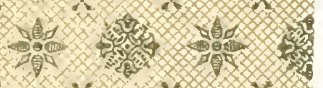

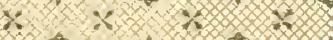

tis

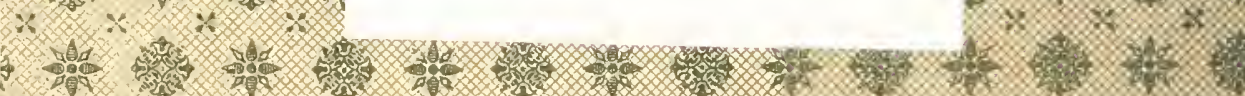

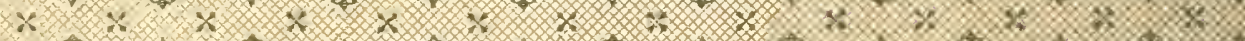

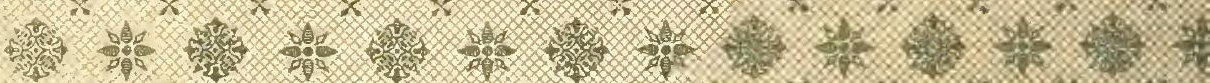

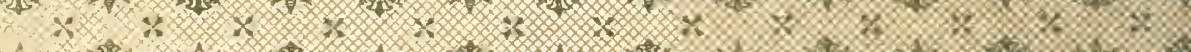

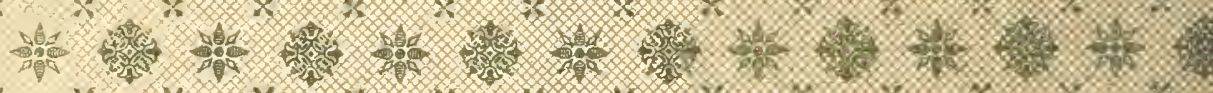

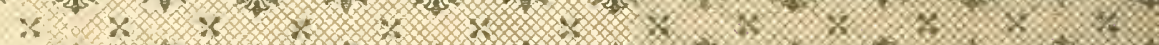

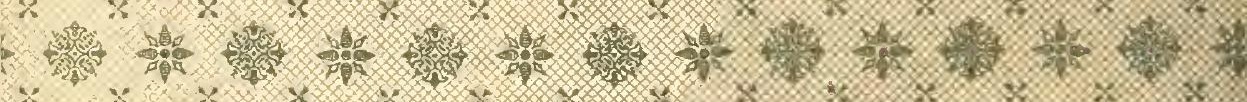

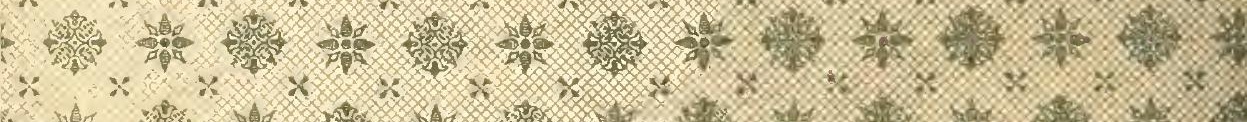
" "

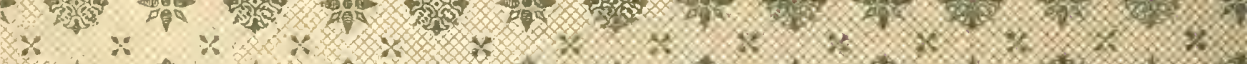

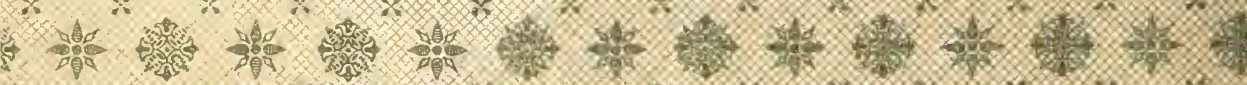

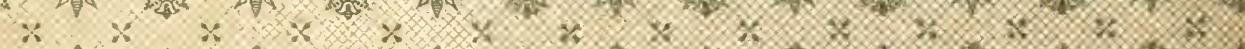

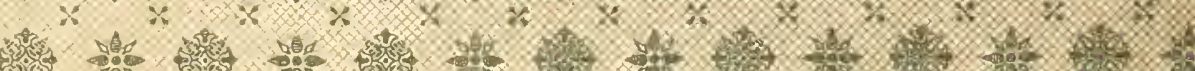
(2)

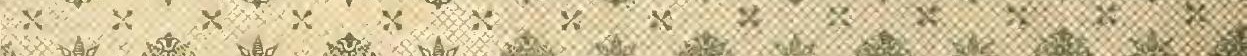

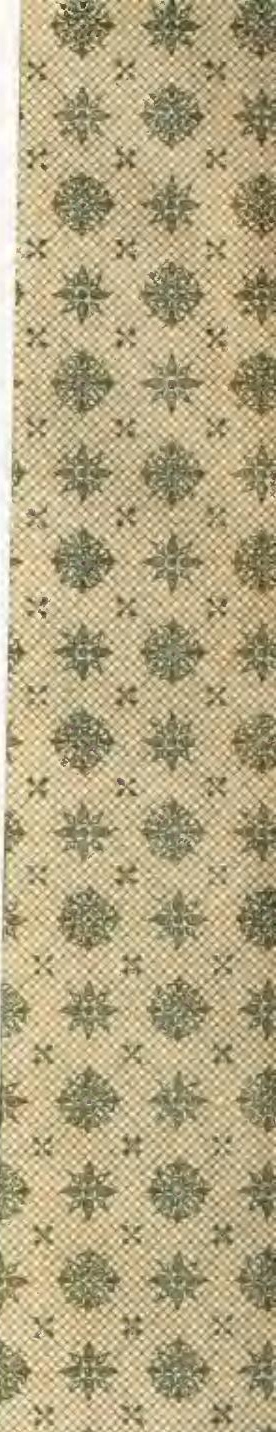


